\title{
Climatic signals from 76 shallow firn cores in Dronning Maud Land, East Antarctica
}

\author{
S. Altnau ${ }^{1,2}$, E. Schlosser ${ }^{1,3}$, E. Isaksson ${ }^{4}$, and D. Divine ${ }^{4}$ \\ ${ }^{1}$ Institute of Meteorology and Geophysics, Centre for Climate and Cryosphere, \\ University of Innsbruck, 6020 Innsbruck, Austria \\ ${ }^{2}$ Deutscher Wetterdienst (DWD), 63067 Offenbach, Germany \\ ${ }^{3}$ Austrian Polar Research Institute, Vienna, Austria \\ ${ }^{4}$ Norwegian Polar Institute, Fram Centre, 9296 Troms $\varnothing$, Norway \\ Correspondence to: S. Altnau (sebastian.altnau@dwd.de)
}

Received: 20 October 2014 - Published in The Cryosphere Discuss.: 2 December 2014

Revised: 11 March 2015 - Accepted: 15 April 2015 - Published: 7 May 2015

\begin{abstract}
The spatial and temporal distribution of surface mass balance (SMB) and $\delta^{18} \mathrm{O}$ were investigated in the first comprehensive study of a set of 76 firn cores retrieved by various expeditions during the past 3 decades in Dronning Maud Land, East Antarctica. The large number of cores was used to calculate stacked records of SMB and $\delta^{18} \mathrm{O}$, which considerably increased the signal-to-noise ratio compared to earlier studies and facilitated the detection of climatic signals. Considerable differences between cores from the interior plateau and the coastal cores were found. The $\delta^{18} \mathrm{O}$ of both the plateau and the ice shelf cores exhibit a slight positive trend over the second half of the 20th century. In the corresponding period, the $\mathrm{SMB}$ has a negative trend in the ice shelf cores, but increases on the plateau. Comparison with meteorological data from Neumayer Station revealed that for the ice shelf regions, atmospheric dynamic effects are more important than thermodynamics while on the plateau; the temporal variations of SMB and $\delta^{18} \mathrm{O}$ occur mostly in parallel, and thus can be explained by thermodynamic effects. The Southern Annular Mode (SAM) has exhibited a positive trend since the mid-1960s, which is assumed to lead to a cooling of East Antarctica. This is not confirmed by the firn core data in our data set. Changes in the atmospheric circulation that result in a changed seasonal distribution of precipitation/accumulation could partly explain the observed features in the ice shelf cores.
\end{abstract}

\section{Introduction}

In the ongoing discussion about climate change, the climate of the polar regions is one of the foci of attention. Whereas the enhanced warming that models predict for the polar regions is obvious in the Arctic (Stocker et al., 2013), Antarctica behaves differently. Not only an increase in sea ice extent is observed (Parkinson and Cavalieri, 2012) but also the expected warming combined with a corresponding increase in precipitation and thus increased surface mass balance is still not observed over the entire Antarctic continent.

Only the wider Antarctic Peninsula region (including parts of West Antarctica) exhibits a large increase in air temperature (Bromwich et al., 2013), accompanied by disintegrating ice shelves and accelerated ice flow (Rignot et al., 2013; Rott et al., 2002). For East Antarctica, no general warming and increase in precipitation is found in surface observational data (Turner et al., 2005; Monaghan et al., 2006, 2008). This is important because an increase in precipitation, and hence increased surface mass balance (SMB), might mitigate sea level rise.

Close monitoring of changes in both the atmosphere and the cryosphere is necessary in order to detect early signs of climatic change in East Antarctica. In particular, the coastal regions are highly sensitive to any changes, since the temperatures are close to the melting point in summer already in the present climate (King and Turner, 1997).

Instrumental surface air temperature records from the Antarctic continent are available only since the International 


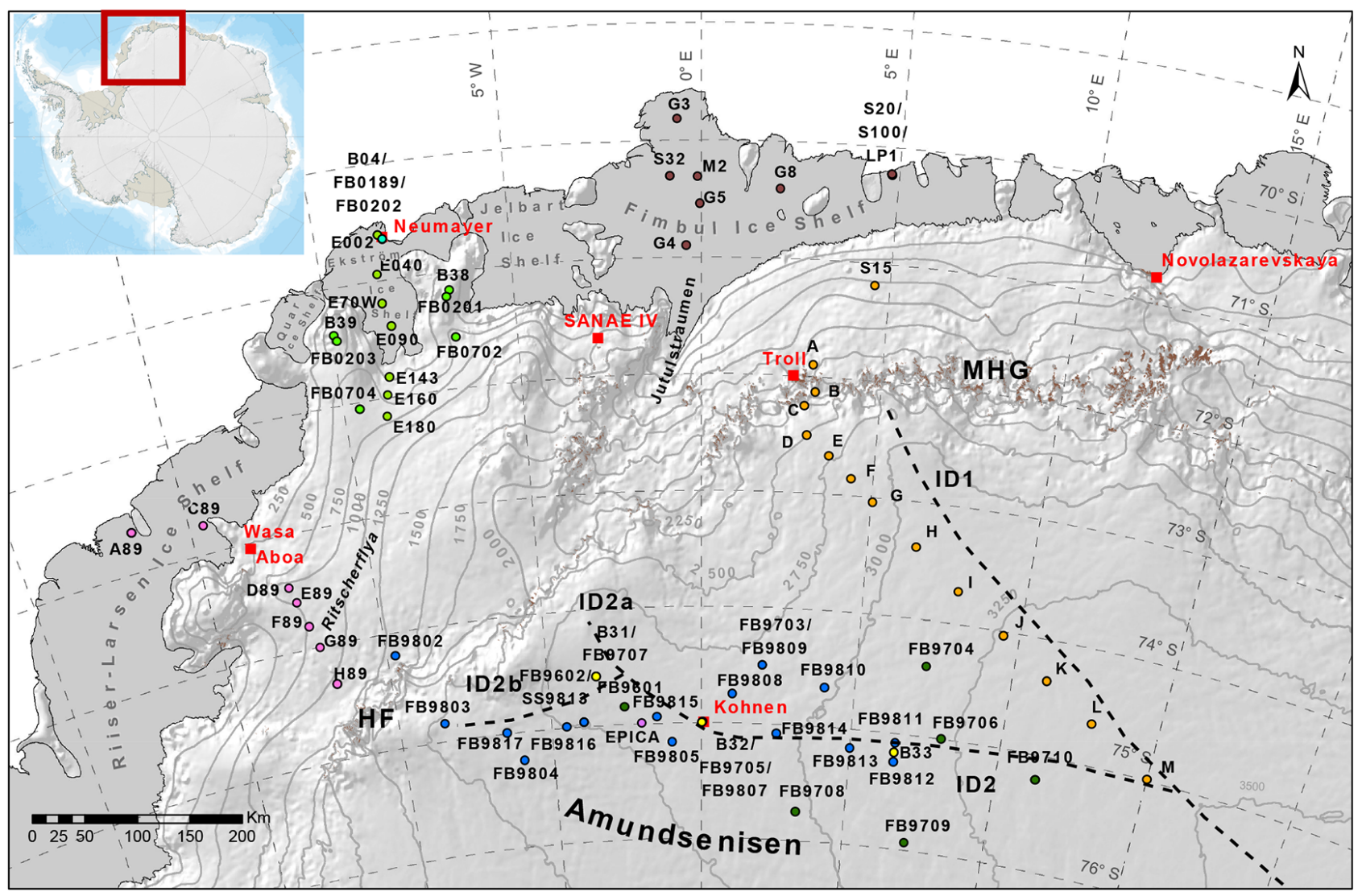

Figure 1. Firn and ice core drill locations in western Dronning Maud Land used in this study (Table A1). Grey lines display the topography with increments of $250 \mathrm{~m}$ (MHG: Mühlig-Hofmann Gebirge (Mühlig-Hofmann Range), HF: Heimefrontfjella, ID: ice divide). Antarctic research stations are labelled in red. Topographic data are used from Antarctic Digital Database (ADD).

Geophysical Year (IGY) 1957-1958. The number of stations is still limited and most of them are situated at the coast. Thus, to investigate the past climate, we have to rely on firn and ice cores. Temperature information is derived mainly from the stable water isotope ratio; annual mean SMB can be calculated from density measurements for cores where annual layers are resolved.

In Dronning Maud Land (DML), East Antarctica (Fig. 1), various expeditions have carried out glaciological field work, including drilling of firn and ice cores in the past decades in the frame of different national and international programmes. In particular, the pre-site-survey expeditions connected to the European Project for Ice Coring in Antarctica (EPICA) (EPICA Community Members, 2006) have increased our knowledge about the hitherto poorly explored DML. Almost 80 cores have been drilled during these expeditions since 1980. However, so far only the results of single expeditions have been published; no comprehensive study of this unique data set had been carried out. In this study, the spatial and temporal variations of stable isotope ratios and SMB derived from a network of 76 cores were investigated. Calculation of stacked records helped to considerably improve the signal-to- noise ratio. The spatial variations were related to topographic and other geographical features. Possible climatic trends in SMB and $\delta^{18} \mathrm{O}$ were investigated. Additionally, the relationship between $\delta^{18} \mathrm{O}$ and SMB and possible influences of the Southern Annular Mode (SAM) as the primary mode of atmospheric variability in the extratropical Southern Hemisphere were analysed.

\section{Field area}

Dronning Maud Land is situated in East Antarctica approximately between $20^{\circ} \mathrm{W}$ and $45^{\circ} \mathrm{E}$. It covers an area of ca. $2700000 \mathrm{~km}^{2}$. Our study is focused on the western part of DML, between $15^{\circ} \mathrm{W}$ and $10^{\circ} \mathrm{E}$ (see Fig. 1). DML is bounded by various ice shelves of different sizes. The westernmost ice shelf, for which cores are available for this investigation, is the Riiser-Larsen Ice Shelf with a width of about $400 \mathrm{~km}$. Further east, the Ekström Ice Shelf is found, which is bounded by two N-S stretching ridges, Søråsen and Halvfarryggen. Centred at the Greenwich meridian is the Fimbul Ice Shelf, with an area of $33000 \mathrm{~m}^{2}$ one of the largest ice shelves in DML. It extends approximately $100 \mathrm{~km}$ in N-S 
direction and $200 \mathrm{~km}$ in E-W direction and is fed by Jutulstraumen, the largest outlet glacier in DML. The lower inland region Ritscherflya is situated south of the Riiser-Larsen and Ekström ice shelves. A mountain range to the southeast, Heimefrontfjella, separates Ritscherflya from the higher plateau area, the so-called Amundsenisen.

\section{Previous work}

Early glaciological measurements were carried out in our study area by the British-Swedish-Norwegian Expedition 1949-1952 (Swithinbank, 1957). Thereafter, DML was only visited sporadically until the early 1980s. Systematic data acquisition began in the 1980s on the Ekström Ice Shelf, connected to the German year-round scientific base Georgvon-Neumayer. Various traverses started at this station since 1986/1987 (Miller and Oerter, 1990). Glaciological field work was performed along the traverse routes from the Ekström Ice Shelf to Heimefrontfjella and, in the frame of EPICA, to Amundsenisen.

More recently, several shallow firn cores were retrieved at Søråsen and Halvfarryggen (Fernandoy et al., 2010). However, these cores are strongly influenced by local topography and are therefore not directly comparable to the other cores. (For the sake of completeness we did not omit them from our study.)

The lower inland region Ritscherflya was visited during the field season 1988/1989 as part of the Swedish Antarctic Research Programme (SWEDARP). The SMB and $\delta^{18} \mathrm{O}$ records generally showed large spatial and temporal variability (Isaksson and Karlén, 1994a, b; Isaksson et al., 1996).

As part of the Norwegian Antarctic Research Expedition (NARE), Norwegian groups investigated the spatial and temporal variability of SMB on a traverse that crossed the Fimbul Ice Shelf (e.g. Isaksson and Melvold, 2002 and Melvold et al., 1998). In austral summer 2000/2001, a $100 \mathrm{~m}$ deep ice core was retrieved on the eastern Fimbul Ice Shelf. The derived accumulation rates showed high temporal variability and a significant negative trend in the 20th century (Kaczmarska et al., 2004).

Divine et al. (2009) used eight firn cores from coastal DML to study the long-term changes in accumulation and $\delta^{18} \mathrm{O}$ in the area and the role of the Southern Annular Mode (SAM) and ENSO (El Niño-Southern Oscillation) in the temporal variability of $\delta^{18} \mathrm{O}$. The study revealed the diverging multidecadal trends in accumulation (decreasing) and $\delta^{18} \mathrm{O}$ (increasing) in coastal DML. On shorter sub-decadal time scales, it was found that the teleconnection of ENSO to the area is stronger in years when the SAM is in its negative phase.

In austral summers 2009-2011, eight shallow firn cores were retrieved on the Fimbul Ice Shelf during an extensive glaciological field campaign as part of the project "Fimbul Ice Shelf from top to bottom" that combined glaciological measurements with oceanographic measurements and modelling (http://fimbul.npolar.no). The $\delta^{18} \mathrm{O}$ exhibited a small positive trend, whereas a negative trend was observed in SMB during the last 30 years (Schlosser et al., 2012; Sinisalo et al., 2013).

The majority of the extensive EPICA pre-site-survey programme was conducted on the high plateau region Amundsenisen. Between 1996 and 1998, a series of shallow firn cores and three medium-deep ice cores (see Appendix Table A1) were drilled on Amundsenisen. The area was found to be characterized by a robust deposition system with nearly constant accumulation rates for the last millennium (Isaksson et al., 1996; Oerter et al., 1999, 2000, 2004; Sommer et al., 2000a, b; Graf et al., 2002; Hofstede et al., 2004; Karlöf et al., 2000, 2005). Oerter et al. (1999) calculated a mean value of $57 \pm 15 \mathrm{~kg} \mathrm{~m}^{-2} \mathrm{a}^{-1}$, with higher values in the western part of Amundsenisen.

Rotschky et al. (2007) used a special interpolation method to derive a surface accumulation map for western DML from firn cores, snow pits, and stake measurements. The accumulation was found to clearly decrease with elevation and distance from the coast, with local maxima and minima on the windward and lee sides of topographic ridges. This was confirmed by Schlosser et al. (2008) who compared Rotschky's results with data from a mesoscale atmospheric model.

Anschütz et al. (2009) presented data from the Norwegian US Scientific Traverse of East Antarctica TASTE-IDEA, through DML from the Norwegian base Troll to the South Pole, during which some earlier Norwegian drilling sites were revisited. The mean accumulation rate at Sites I and M (Isaksson et al., 1999, see also Fig. 1) has not changed since the earlier measurements. Fujita et al. (2011) investigated the spatial and temporal variability of accumulation in DML using snow pits, firn cores and radar data from an IPY traverse between Kohnen Station and Dome Fuji (along ID2, Fig. 1 and further east). They found a positive trend in accumulation for central DML in the past 50 years. Frezzotti et al. (2013) provided a synthesis of Antarctic SMB during the last 800 years. They stated that SMB over most of Antarctica does not exhibit an overall clear trend. However, they found a clear increase in SMB in coastal regions and over the highest part of the East Antarctic ice divide since the 1960s, which confirms the results of Fujita et al. (2011) but contradicts those of Divine et al. (2009) and Kaczmarska et al. (2004). Anschütz et al. (2011) used volcanic time markers to investigate century-scale SMB changes in ice cores retrieved during the above-mentioned traverse from Troll to South Pole but found that almost all sites above $3200 \mathrm{~m}$ altitude show a decrease in SMB in the last 50 years. 
Table 1. Time periods and number of contributing cores for the composite records for western DML. "Ice shelves" corresponds to all cores from the Fimbul, Ekström and Riiser-Larsen ice shelves. "Ekström $(R)$ " refers to all cores from the Ekström Ice Shelf plus the adjacent ridges Søråsen and Halvfarryggen.

\begin{tabular}{lrr}
\hline Region & Period & $\begin{array}{r}\text { Number of } \\
\text { cores }(N)\end{array}$ \\
\hline Fimbul Ice Shelf & $1950-2009$ & 9 \\
Ekström Ice Shelf & $1950-2001$ & 7 \\
Ekström Ice Shelf $(R)$ & $1950-2006$ & 16 \\
Ice shelves & $1950-2009$ & 18 \\
Ritscherflya & $1970-1988$ & 6 \\
Plateau & $1950-1997$ & 30 \\
\hline
\end{tabular}

\section{Data and methods}

\subsection{Shallow firn core data}

The available data set consists of 76 shallow firn and ice cores carried out during different field campaigns over a time period of about 3 decades. Figure 1 shows the location of all firn cores used during this study. In Table A1 detailed information about each core can be found. The time period covered by the cores ranges from approximately 30 to 200 years, two cores reach an age of 1000 years, one core almost 2 millennia. Spatially the data set represents the entire western DML. In this study, we use SMB and $\delta^{18} \mathrm{O}$ data. The cores were dated mainly using the seasonality of stable isotope ratios $\left(\delta^{18} \mathrm{O}, \delta \mathrm{D}\right)$, supplemented by dielectric profiling (DEP) (Wilhelms et al., 1998), continuous flow analysis (CFA) (Oerter et al., 2000; Sommer et al., 2000a), and, in the earlier days, electrical conductivity measurements (ECMs) (Hammer et al., 1980) and $\beta$-activity measurements (Isaksson and Karlén, 1994a, b). Continuous flow analysis allowed fast analysis of ammonium, calcium, and sodium along the ice core with a high resolution (Röthlisberger et al., 2000; Sommer et al., 2000b). The average dating error for single years is given as approximately \pm 2 years (Isaksson et al., 1999; Oerter et al., 2000; Schlosser et al., 2012, 2014) for the short cores spanning the last few decades. For the cores covering centennial scales the dating error is larger, but difficult to quantify since it depends not only on accumulation rate, but also on wind scouring that is very irregular and individual.

\subsection{Composite records}

Annual values of SMB and mean annual $\delta^{18} \mathrm{O}$ of different cores are poorly correlated, even records from the same drilling location. This is partly due to the large depositional noise due to the effects of wind, which particularly affects SMB values. Furthermore, as the annual SMB series generally demonstrate an increased variance at higher frequen- cies (so-called "blue noise" properties, Fisher et al., 1983), a shift of 1 or 2 years due to dating errors can considerably reduce the quality of the correlation when no smoothing of the record is done. In order to reduce depositional noise and enhance the signal-to-noise ratio (see Sect. 4.5.1), stacked records of $\delta^{18} \mathrm{O}$ and SMB were calculated. For this calculation, the cores were divided into several sub-groups, according to geographical region and longest possible common time period covered. Table 1 shows the different core groups together with their corresponding time periods and number of cores. The first set of shallow firn cores comprises 10 cores drilled in the vicinity of Neumayer Station (Miller and Oerter, 1990; Schlosser and Oerter, 2002a, b). The second group includes these cores plus six more cores situated on Søråsen and Halvfarryggen (Fernandoy et al., 2010). However, as stated before, these cores are strongly influenced by local conditions; thus this group has to be considered with care.

Eight cores retrieved during a recent expedition on the Fimbulisen (Schlosser et al., 2012, 2014) together with two older cores from the same area (Kaczmarska et al., 2004) form the third group. All ice shelf cores together were combined in the fourth group. Seven cores from the southwestern corner of the study area, Riiser-Larsen Ice Shelf and Ritscherflya, drilled during austral summer 1988/1989 (Isaksson and Karlén, 1994a, b) represent another group.

The last group contains all 30 cores from the plateau on Amundsenisen. The plateau cores cover on average a time period of 200 years; also the three medium-deep cores, B31B33) are found here. (The data of the plateau and Ekström cores are provided by Alfred-Wegener-Institute (AWI), Helmholtz Center for Polar and Marine Research at www. pangaea.de.) In the discussion of the results, we will refer to these sub-groups. Note that the cores shown in orange in Fig. 1 along Ice Divide 1 are given only for the sake of completeness and are not used in the stacked records due to data loss on annual SMB and mean $\delta^{18} \mathrm{O}$ from this expedition.

Since the cores are situated in different climatic regions (ice shelf, plateau, and transition zone) with considerable differences in mean precipitation amounts and temperatures, for each core the deviations from the local mean were calculated before averaging over all cores of the corresponding group and time period. For SMB, the coefficient of variation (the relative deviation expressed as a percentage of the mean) was used, since accumulation rates range from approximately 30 to several hundreds $\mathrm{kg} \mathrm{m}^{-2}$.

\subsection{Climatological data}

To compare the $\delta^{18} \mathrm{O}$ series with air temperature data, longterm meteorological measurements would be required. For the plateau region of western Dronning Maud Land, no data from the 20th century are available. An automatic weather station (AWS) was installed $1.5 \mathrm{~km}$ west of Kohnen Station already in 1998 and moved to the station in 2007. In coastal 
Dronning Maud Land, several year-round stations exist. The first operational meteorological data in DML were provided by the British base Halley, which was established in 1956 on the Brunt Ice Shelf in the frame of the International Geophysical Year 1957-1958. Due to its southern location $\left(75^{\circ} \mathrm{S}\right)$ at the coast of the ice-covered Weddell Sea, it is not representative of the climate of the DML ice shelves. The Russian base Novolazarevskaya was built in a partly snow-free oasis, which also exhibits very local features. SANAE, the South African base, was moved several times and has no homogenous time series. Thus, the only suitable station for our purpose is the German base Neumayer on the Ekström Ice Shelf (see Fig. 1), built in 1981. The climate of Neumayer is typical for the ice shelves of DML, and thus the data can be used for comparison with the ice shelf cores (König-Langlo et al., 1998).

\subsection{SAM index}

The Southern Annular Mode (SAM) is the principal mode of atmospheric variability of the extratropical Southern Hemisphere. It is revealed as the leading empirical orthogonal function (EOF) in geopotential height, surface pressure, surface temperature, zonal wind and many other atmospheric fields (Marshall, 2003). Since the pressure fields from global reanalyses show relatively large errors in the polar regions, Marshall (2003) defined an SAM index using the mean pressure difference between 40 and $65^{\circ} \mathrm{S}$ based on observational data. A positive (negative) SAM index corresponds to a strong (weak) meridional pressure gradient. Thus the positive phase of SAM is characterized by strong, mostly zonal westerlies with only low amplitudes of planetary waves. This means little exchange of moisture and energy between mid and high latitudes (Marshall, 2013) and consequently a cooling of Antarctica, with the exception of the Antarctic Peninsula, which projects farther north then the rest of the continent. To examine the possible influence of SAM on accumulation and $\delta^{18} \mathrm{O}$ of the firn cores, in this study we use the annual SAM index as defined by Marshall (2003). The data are provided by the British Antarctic Survey (BAS) at http://www.antarctica.ac.uk/met/gjma/sam.html.

\subsection{Statistical methods}

\subsubsection{Signal-to-noise ratio}

The stacked records are also used to investigate the deposition noise of $\delta^{18} \mathrm{O}$ and SMB. The signal-to-noise variance ratio (SNVR) of a single record $F_{\mathrm{i}}$ can be estimated (Johnsen et al., 1997) by comparing the variance of a stacked record $\left(\mathrm{VAR}_{\mathrm{C}}\right)$ derived from $N$ individual records to the mean variance of the $N$ individual records $\left(\mathrm{VAR}_{\mathrm{M}}\right)$ :

$F_{\mathrm{i}}=\left[\mathrm{VAR}_{\mathrm{C}}-\mathrm{VAR}_{\mathrm{M}} / N\right] /\left[\mathrm{VAR}_{\mathrm{C}}-\mathrm{VAR}_{\mathrm{M}}\right]$
Table 2. Signal-to noise variance ratio of $\delta^{18} \mathrm{O}$ and SMB in the individual records $\left(F_{\mathrm{i}}\right)(N)$ (see Eq. 1) compared to the composite records $\left(F_{\mathrm{c}}\right) \cdot F_{\mathrm{c}}$ is determined by multiplying $F_{\mathrm{i}}$ with the number of individual cores contained in the composite record.

\begin{tabular}{lrrr}
\hline Composite record & Parameter & $F_{\mathrm{i}}$ & $F_{\mathrm{c}}$ \\
\hline Ice shelves & $\delta^{18} \mathrm{O}$ & 0.35 & 4.2 \\
& $\mathrm{SMB}$ & 0.39 & 4.7 \\
\hline Plateau & $\delta^{18} \mathrm{O}$ & 0.09 & 2.7 \\
& $\mathrm{SMB}$ & 0.07 & 2.1 \\
\hline Plateau & $\delta^{18} \mathrm{O}$ & 0.14 & 4.1 \\
$(200 \mathrm{a})$ & $\mathrm{SMB}$ & 0.06 & 1.7 \\
\hline
\end{tabular}

with $\mathrm{VAR}_{\mathrm{M}}$ : mean variance of the individual records, $\mathrm{VAR}_{\mathrm{C}}$ : Variance of the composite record, N: number of individual records contained in the stacked record.

In Table 2, for each subgroup (ice shelf cores, plateau cores, and the 200-year series of the plateau cores) the SNVR of the single records (mean of all cores of one group) $F_{\mathrm{i}}$ compared to the corresponding composite record $F_{\mathrm{c}}$ is shown. $F_{\mathrm{c}}$ is determined by multiplying $F_{\mathrm{i}}$ with the number of individual cores contained in the composite record. Generally, the SNVR is higher for the ice shelf cores than for the plateau cores, and on the plateau, also higher for $\delta^{18} \mathrm{O}$ than for SMB. On the plateau, accumulation rates are considerably lower than in the coastal areas. At the same time, the effects of wind scouring and thus disturbance of the annual layers are larger, which leads to higher variance in the plateau cores than in the coastal cores.

It turned out that it did not make sense to calculate a stacked record of all available cores since the temporal changes of SMB and $\delta^{18} \mathrm{O}$ were systematically different in the coastal cores and the plateau cores. However, the signalto-noise ratio in the two large sub-groups of cores in this study is considerably higher than in earlier studies where a maximum of 12 cores (Oerter et al., 2000) and 16 cores (Graf et al., 2002) was used (see also Sect. 5.2.2).

\subsubsection{Trends and correlations}

The statistical significance of correlations and trends described in this study is assessed using specific procedures and statistical tests: the linear trends are calculated for time periods of at least 30 years in order to obtain reliable results independent on short-term (interannual) variability. As a testing procedure for statistically significant trends, the $F$ test is used. To check the statistical significance, the $F$ test is essentially defined as ratio of the variance of the data "explained" by the model and the "unexplained variance". The period 1950-2000 was chosen as the longest common period covered by a large number of cores. After the year 2000, only data from the Fimbul Ice Shelf are available for this study. 


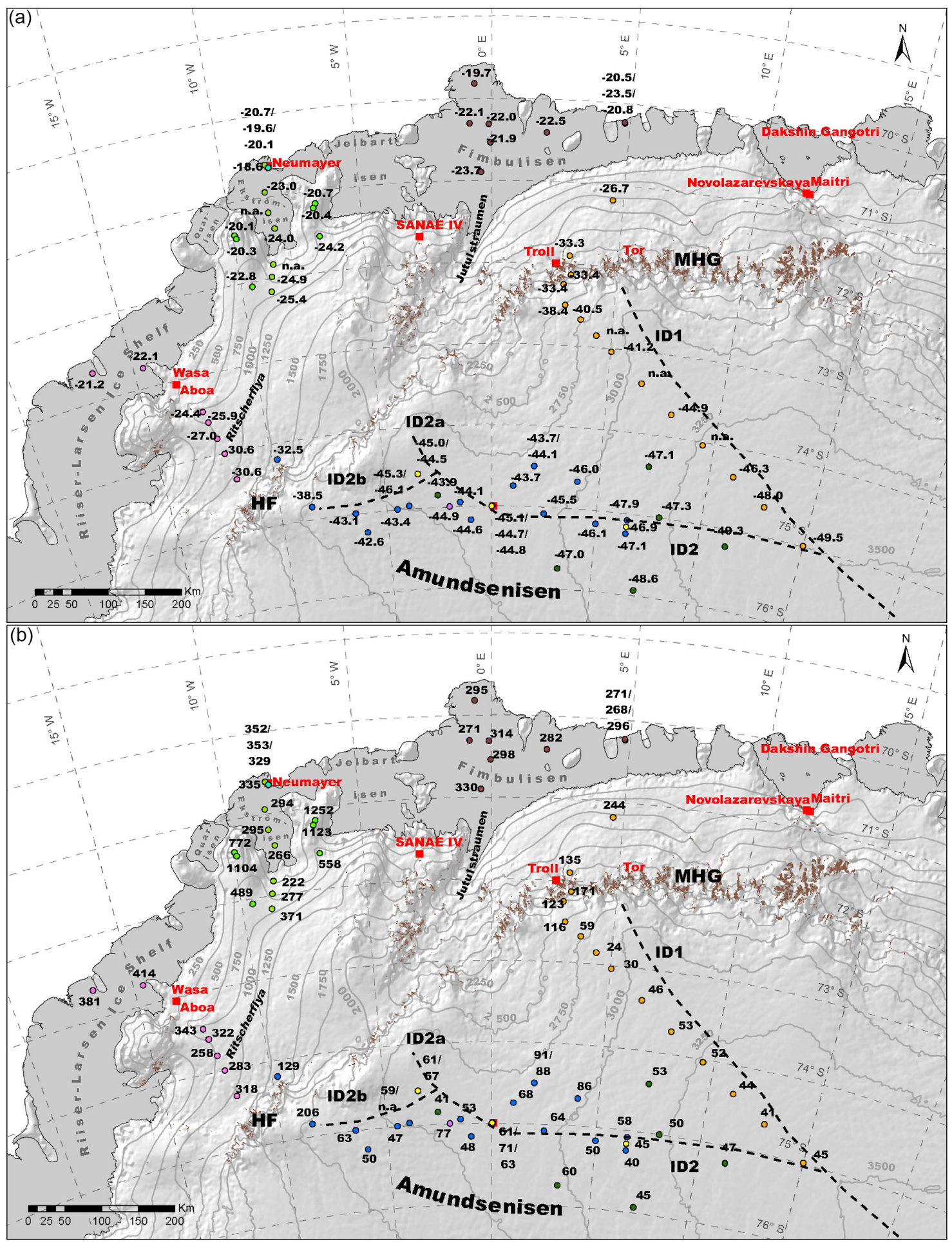

Figure 2. (a) Mean annual $\delta^{18} \mathrm{O}(\%)$ for the complete time series of each core. Labels in (a) and (b) are arranged in the same way as in Fig. 1 (NA: not available). (b) Mean annual SMB $\left(\mathrm{kg} \mathrm{m}^{-2}\right)$ for all firn and ice cores (NA: not available). 


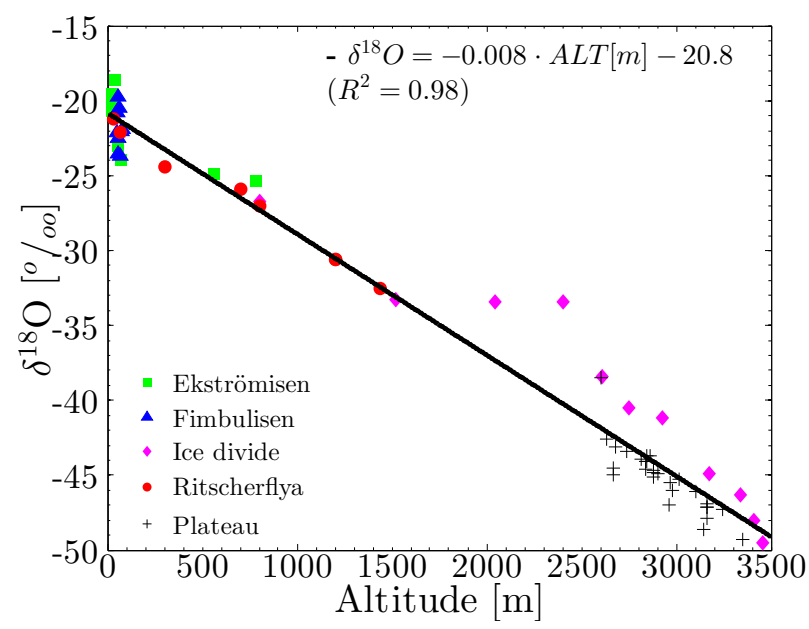

Figure 3. Core average $\delta^{18} \mathrm{O}$ plotted vs. core site altitude. Solid black lines show the respective linear fits to the data. Cores from different regions of the study area are shown in different colours and symbols.

In order to reveal possible causal links between the atmospheric forcing, regional SMB and $\delta^{18} \mathrm{O}$ in annual snow accumulation we calculated cross correlations between the series of SAM, the composite records of $\delta^{18} \mathrm{O}$ and SMB. Prior to the procedure the series were normalized and detrended for the periods of overlap. First the means and deviation of these means are determined for the common periods of each combination of the composite records. Then these records are detrended, which assumes that there is no link between possible linear trends in the predictor (i.e. SAM) and the predictand $\left(\delta^{18} \mathrm{O}, \mathrm{SMB}\right)$. This will yield slightly stronger (weaker) correlations if the trends in the composite records are of opposite (the same) sign. The significance of the correlations is determined using the standard $t$ test. If the original undetrended data were used, this method would assume that the trend in the predictand $\left(\delta^{18} \mathrm{O}, \mathrm{SMB}\right)$ is entirely due to the predictor (i.e. SAM). The reality most likely lies somewhere between those two assumptions and a robust causal quantitative relationship between the variables at the time scale of the whole series cannot be established. The effects of possible autocorrelation in the series were accounted for in the testing procedure via adjustment of the number of degrees of freedom.

\section{Results}

\subsection{Spatial distribution of $\delta^{18} \mathrm{O}$ and SMB}

Figure 2 shows the mean values of $\delta^{18} \mathrm{O}$ (Fig. 2a) and SMB (Fig. 2b) for each core. Note that the time intervals, for which the averages are calculated, are different. Therefore, spatial differences between the individual cores could partly be due to temporal changes in annual $\delta^{18} \mathrm{O}$ and SMB. However, we note that the mean values of $\delta^{18} \mathrm{O}$ and SMB for cores of different age from the same drilling site agree well within the error bounds, particularly on the plateau.

Both $\delta^{18} \mathrm{O}$ and SMB are strongly related to geographical factors such as distance to the coast and elevation. The influence of the distance to the coast, continentality, affects both temperature and precipitation.

Mean $\delta^{18} \mathrm{O}$ values range from $-49.5 \%$ at the southeastern corner of the study area on Amundsenisen (elevation almost 3500 ma.s.1.) to a maximum of $-18.6 \%$ close to Neumayer Station at an elevation of $30 \mathrm{ma}$ a.s.l. A strong linear correlation $\left(R^{2}=0.98\right)$ is found between the altitude at the drilling location and mean $\delta^{18} \mathrm{O}$ of the cores. Results displayed in Fig. 3 suggest an average decrease in $\delta^{18} \mathrm{O}$ of approximately $8 \% \mathrm{~km}^{-1}$. In contrast to other studies, which state that the relationship between altitude and stable isotopes in precipitation depends on the altitude range because of differences in moisture transport (e.g. Masson-Delmotte et al., 2008), in our study we find that the same linear relationship holds for the entire range of altitudes covered by the cores (approximately 0-3500 ma.s.l.). A relatively large scattering of data points around the fitted line is observed only for the cores from locations close to sea level. As the threedimensional moisture transport to Antarctica is not fully understood yet, the altitude range dependence described by Masson-Delmotte et al. (2008) presently cannot be explained physically.

The cores from Søråsen and Halvfarryggen were not included in the calculation of the $\delta^{18} \mathrm{O}$-elevation relationship since the accumulation at these core sites is strongly influenced by local topography. They show mean annual $\delta^{18} \mathrm{O}$ values similar to the Neumayer cores, which implies no significant altitude effect for these sites. The atmospheric processes that cause these anomalies are not yet understood.

The SMB depends mainly on altitude and continentality and is strongly influenced by topographic features. Particularly in the Mühlig-Hofmann Range (MHG), the local influence or the mountains clearly leads to deviations from the general altitude dependence of SMB. Apart from the effect of the mountain ranges, the larger scale topography, namely the ice divides (dashed lines in Figs. 1 and 2) has an influence on SMB depending on the dominant wind direction. Both Schlosser et al. (2008) and Fujita et al. (2011) note that the main wind direction along ID1 is NE. Additionally, Schlosser et al. (2010) showed that during major precipitation events, the flow came more often from the N-NE sector than from the NW. This means that the cores along ID1 are all situated on the lee side of the ridge. The SMB values found here are generally lower than on the windward side of ID2 at similar elevation. Also, SMB is generally lower on the lee side of ID2 than on the windward side. Even though the difference is relatively small, our findings confirm the results of Fujita et al. (2011), who found that SMB is generally lower at the lee side of the ice divides in DML. 
Figure 4 shows the dependence of SMB on altitude. A linear correlation between SMB and altitude is found, however, not as strong as between $\delta^{18} \mathrm{O}$ and altitude $\left(R^{2}=0.90\right)$ due to the generally higher spatial variability of the SMB.

The box plot in Fig. 5 summarizes statistical information on the SMB calculated from the stacked records of the corresponding regional sub-groups of cores. The red line indicates the median. The tops and bottoms of each box are the 25th and 75th percentiles; the distances between the tops and bottoms are the interquartile ranges. Whiskers are drawn from the ends of the interquartile ranges to the furthest observations within the whisker length, the latter corresponding to 1.5 times the interquartile range. Values beyond the whisker length are marked as outliers and plotted as red dots. Again, the group that contains the cores on Halvfarryggen and Søråsen, shows extraordinary amounts of SMB due to the local topographic influence.

\subsection{Temporal variability of regional composite records}

\subsubsection{Stacked records of shallow firn cores}

In Fig. 6, 60-year time series of mean annual $\delta^{18} \mathrm{O}$ and SMB for the different composite records are presented. Both annual means and 5-year running means are shown to highlight the interannual variability. The grey bars on the panels indicate the number of cores used in the calculation of the stacked records.

The stable isotope ratio for the Ekström (Fig. 6a and b) and Fimbul (Fig. 6c) ice shelves is characterized by values generally lower than the multidecadal average during the periods 1950 to the mid-1960s and the 1980s, whereas the 1970s exhibits values above the mean. Ritscherflya (Fig. 6d) has only a short record, but agrees well with Ekström and Fimbul for the given period. For the last 20 years the smoothed record of $\delta^{18} \mathrm{O}$ shows little variation. The $\delta^{18} \mathrm{O}$ of the plateau cores (Fig. 6e) behaves similar to the ice shelf cores, with the exception of slightly higher values around 1960. The similar temporal variability between the different drilling sites is supported by the calculation of cross-correlations. Only 3 of 11 cross-correlations between the detrended composite records of $\delta^{18} \mathrm{O}$ but 9 cross-correlations between the smoothed records (5-year running mean) are found to be statistically significant at the $95 \%$ confidence level according to Student's $t$ test.

The linear trends in $\delta^{18} \mathrm{O}$ for the regionally stacked records were calculated for different time periods according to the data availability. The detailed results are given in Table A2. In Fig. 7, linear trends for the composite records of $\delta^{18} \mathrm{O}$ (Fig. 7a) and SMB (Fig. 7b) are displayed. For the period from 1950 to $2000, \delta^{18} \mathrm{O}$ of the ice shelf cores increases significantly ( $95 \%$ confidence level) by on average $0.18 \%$ decade $^{-1}$. In the plateau cores, this increase is visible, but the positive trend is not statistically significant for the considered period. The largest contribution to this posi-

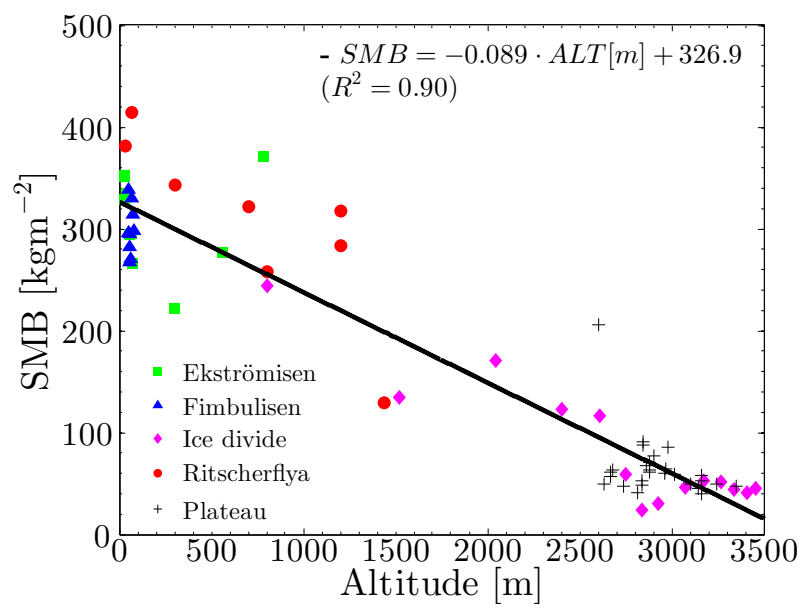

Figure 4. Core average SMB plotted vs. core site altitude. Solid black lines show the respective linear fit to the data. Cores from different regions of the study area are shown in different colours and symbols.

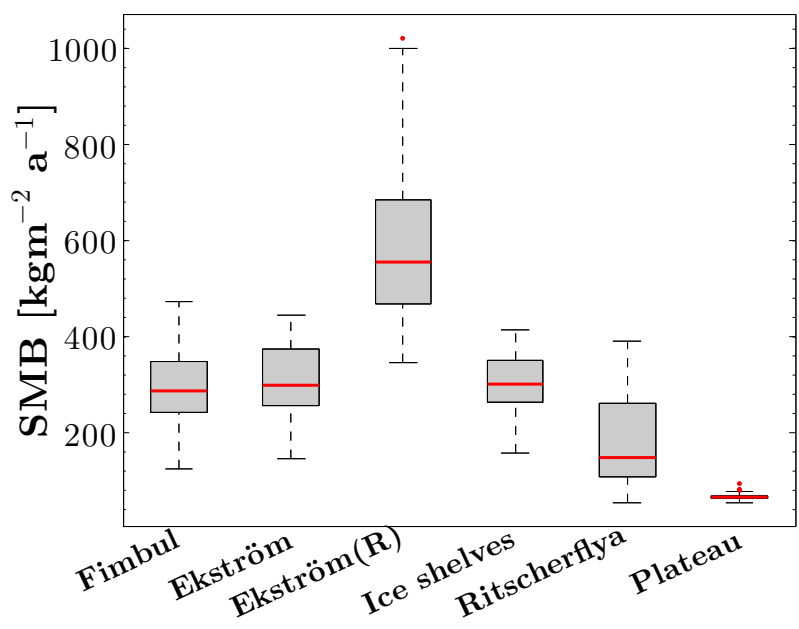

Figure 5. Box plot for the SMB of the stacked records. The red line indicates the median. The tops and bottoms of each box are the 25th and 75th percentiles; the distances between the tops and bottoms are the interquartile ranges. Whiskers are drawn from the ends of the interquartile ranges to the furthest observations within the whisker length, the latter corresponding to 1.5 times the interquartile range. Values beyond the whisker length are marked as outliers and plotted as red dots.

tive trend stems from the period 1950-1980 (see Fig. 6, Table A2), for which also the plateau cores exhibit a significantly positive trend. (The cores from Ritscherflya were excluded for the trend calculation due to the shortness of the data series.)

The analysis of the stacked SMB series reveals a generally less uniform picture of temporal changes in the regional SMB: whereas on the plateau, a positive trend in SMB is observed (significant at the $90 \%$ confidence level), the ice shelves show a negative trend, which is statistically signif- 

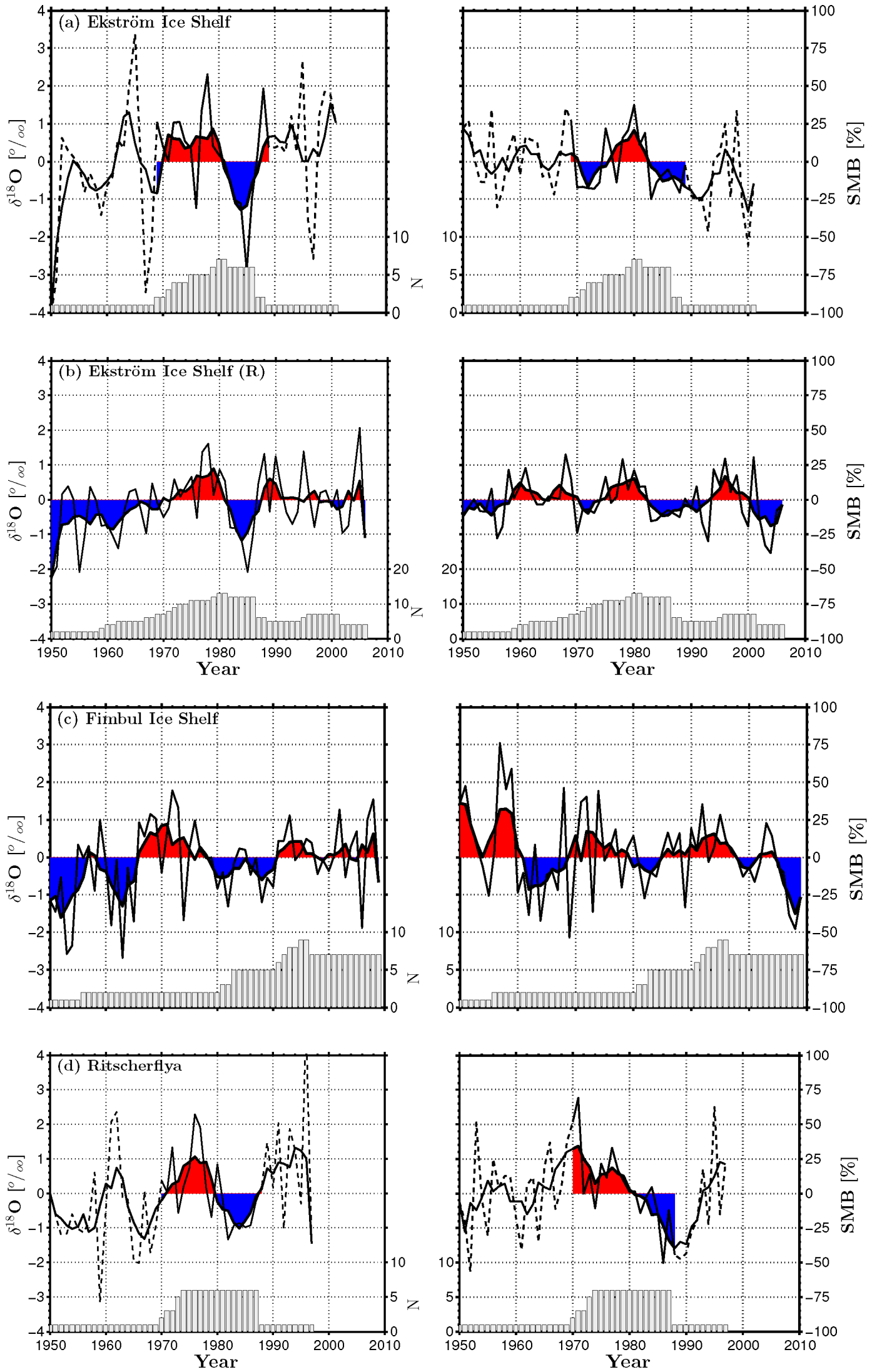

Figure 6. 

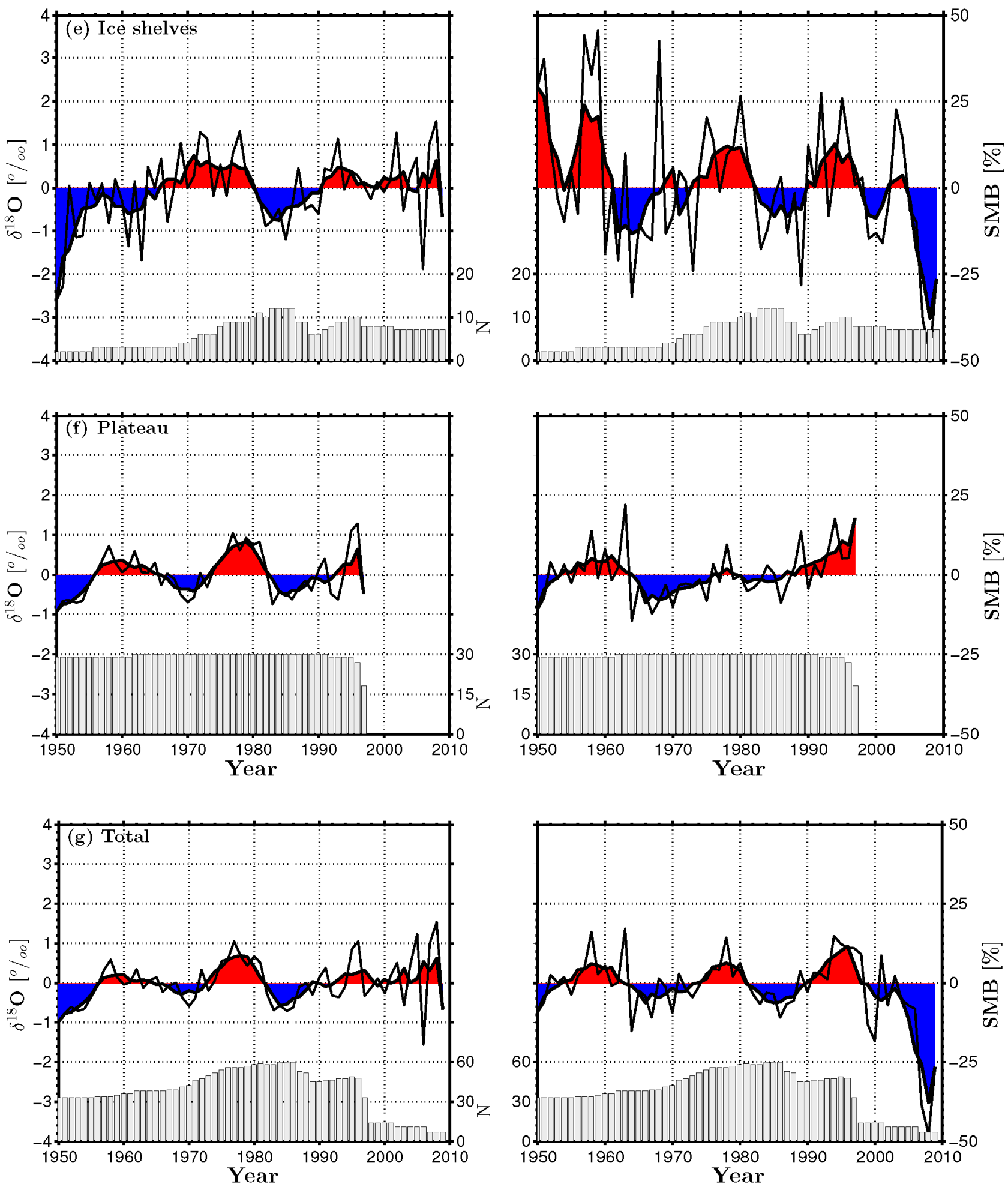

Figure 6. Composite records of $\delta^{18} \mathrm{O}$ as deviation from the mean (\%o) (left) and the SMB as deviation from the mean (\%) (right): (a) Ekström Ice Shelf, (b) Ekström Ice Shelf and adjacent ridges, (c) Fimbul Ice Shelf, (d) Ritscherflya, (e) ice shelves (all), (f) plateau and (g) total. Also shown is a 5-year moving average (thick red and black lines). The grey bars indicate the number of cores that contribute to the composite records. The shaded areas represent time periods with positive (red) and negative (blue) deviations from mean. 

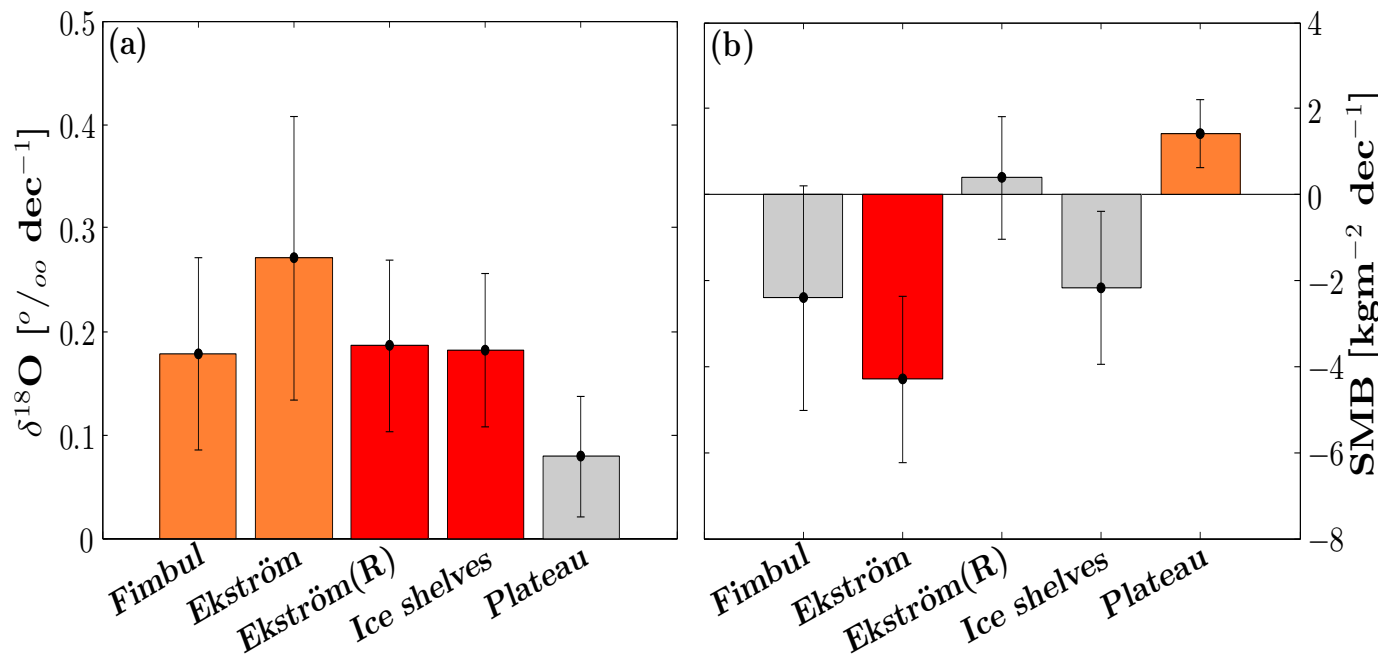

Figure 7. Linear trends for composite records of (a) $\delta^{18} \mathrm{O}$ and (b) SMB per decade between 1950-2000. Statistically significant trends on the $95 \%(90 \%)$ confidence level according to $F$ test are shown as red (orange) bars. Trends with lower significance are coloured in grey. The black error bars represent the standard deviation of the slope.
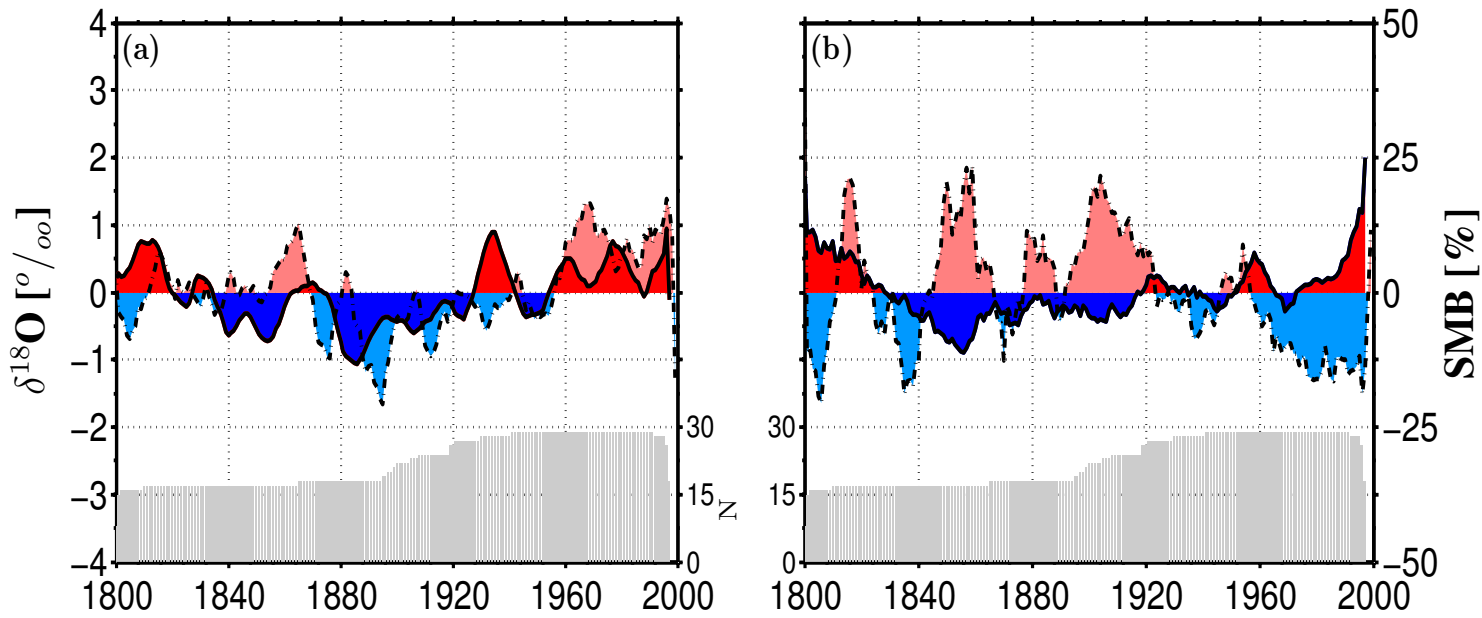

Figure 8. Composite records (11-year moving average) of (a) $\delta^{18} \mathrm{O}$ as deviation from the mean (\%o) and (b) SMB as deviation from the mean $(\%)$ for the plateau (solid line) and coastal region (dashed) for the last 2 centuries. The grey bars indicate the number of cores that contribute to the composite record of the plateau. The ice shelf record consists only of S100 and B04. Shading: time periods with positive (red) and negative (blue) deviations from the mean.

icant only on the Ekström Ice Shelf with a magnitude of $-4.30 \mathrm{~kg} \mathrm{~m}^{-2} \mathrm{decade}^{-1}$ for the studied period. For 1980 2009 , the negative trend becomes significant for the composite record of all ice shelves $\left(-7.25 \mathrm{~kg} \mathrm{~m}^{-2} \mathrm{decade}^{-1}\right)$. The detailed results of the SMB trend analysis are presented in Table A3.

\subsubsection{Intermediate-depth ice cores}

For Amundsenisen, additional composite records that extend back to 1800 were calculated. This has so far been done with only a subset of the cores by Oerter et al. $(1999,2000)$ and Graf et al. (2002). Using a composite of all available cores increases the signal-to-noise variance ratio from 2.2 to $4.1\left(\delta^{18} \mathrm{O}\right)$ and from 0.64 to 1.7 (SMB) (see Table 2). Figure 8 illustrates the 11-year running means of the composite time series of $\delta^{18} \mathrm{O}$ (Fig. 8a) and SMB (Fig. 8b) for the plateau cores and for the two intermediate-depth ice shelf cores, S100 and B04 (see Fig. 1, Table A1) for the time period $1800-1997$. In the first half of the 19th century, the $\delta^{18} \mathrm{O}$ and SMB generally decrease with $0.23 \% \circ$ and $-2.4 \mathrm{~kg} \mathrm{~m}^{-2}$ $(-4.2 \%)$ per decade, respectively. After a minimum around 1850 and again $1885, \delta^{18} \mathrm{O}$ increased in the 20th century. The SMB shows positive deviations from the mean in the first part of the 19th century, followed by a longer negative period from approximately 1830 to 1910 . Thereafter, small negative 

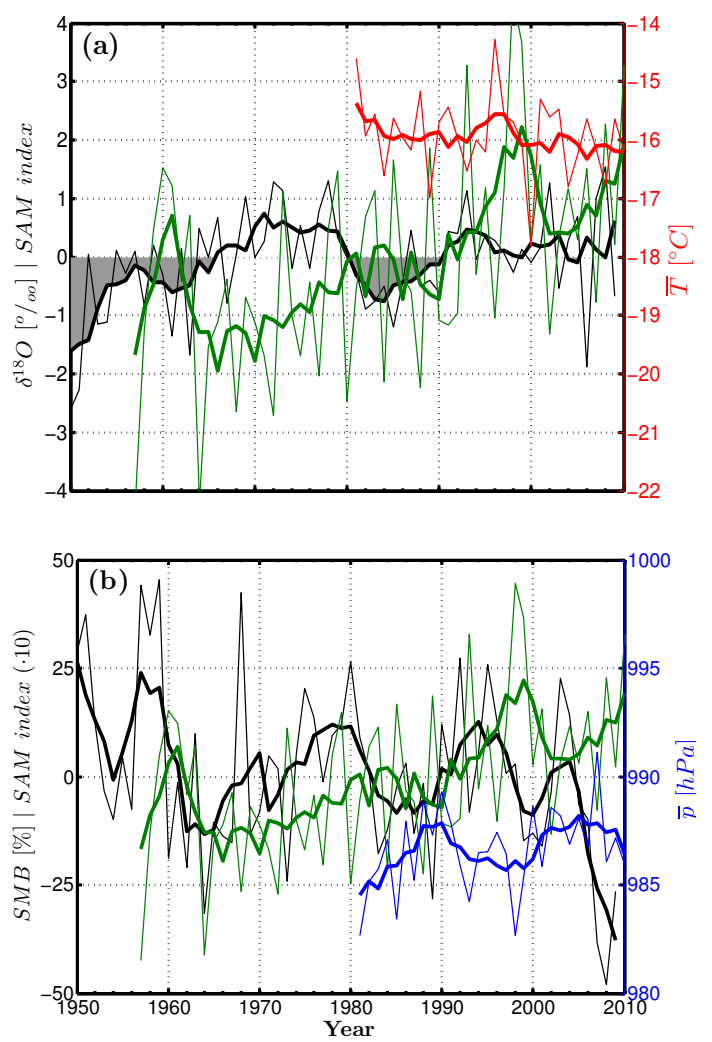

Figure 9. (a) Time series of mean annual $\delta^{18} \mathrm{O}$ of composite record ice shelves (black), annual mean air temperature of Neumayer Station (red) and annual SAM index (green). (b) Mean annual SMB of composite record ice shelves (black), annual mean pressure of Neumayer Station (blue), and annual SAM index (green). Bold lines: 5-year moving average.

deviations occur only during brief time periods, and from the late 70s on, a stronger increase in SMB is observed. The Little Ice Age (LIA), a colder period widely seen in the Northern Hemisphere between 1650 and 1850 is not clearly present in DML. In a 1000-year chronology from Amundsenisen, this period is characterized by strong fluctuations of $\delta^{18} \mathrm{O}$ and SMB around the mean (Graf et al., 2002). Our study covers only the second half of the LIA and the relatively cool period in the second half of the 19th century (seen in Fig. 8) cannot clearly be related to the LIA in the Northern Hemisphere.

The two ice shelf cores (B04 and S100) show a fairly different picture. Apart from the first 40 years of the common period, the SMB inferred from the coastal cores and plateau cores exhibit almost opposite trends. For $\delta^{18} \mathrm{O}$, the picture is less uniform: periods where coastal and plateau $\delta^{18} \mathrm{O}$ are in phase vary with anti-phase periods. Note that the ice shelf "composite record" consists of only two cores. However, they show a similar variability at multidecadal scales, although they were drilled on two different ice shelves.

\subsubsection{Relationship between $\delta^{18} O$ and SMB}

On Amundsenisen, $\delta^{18} \mathrm{O}$ and SMB show fairly similar long-term temporal variations. For the 200-year series the smoothed records are positively correlated (statistically significant at the $95 \%$ level, $r=0.59$ ). Also for the shorter time period 1950-2000, both stable isotope ratio and SMB show positive trends. On the contrary, the ice shelf cores exhibit positive trends of $\delta^{18} \mathrm{O}$ for this period, whereas SMB has been decreasing. Generally, a positive correlation is assumed between $\delta^{18} \mathrm{O}$ and SMB due to the linear relationship between $\delta^{18} \mathrm{O}$ and air temperature and the temperature dependence of the saturation vapour pressure. This means that warmer (colder) air is usually associated to higher (lower) SMB. However, apart from this thermodynamic influence, there are dynamic influences, which seem to be more important for the coastal cores than in the interior and will be discussed in Sect. 6.

\subsection{Possible influence of SAM on $\delta^{18} \mathrm{O}$ and SMB}

In order to investigate the influence of atmospheric dynamics on our results, as a first step, a possible influence of SAM on $\delta^{18} \mathrm{O}$ and SMB was considered. It has to be kept in mind, though, that SAM typically explains only approximately $35 \%$ of the extratropical Southern Hemisphere climate variability (Marshall, 2007). Figure 9 displays the stacked record of mean annual $\delta^{18} \mathrm{O}$ (Fig. 9a) and annual SMB (Fig. 9b) from all ice shelf cores together with annual mean $2 \mathrm{~m}$ air temperature and surface pressure at Neumayer Station. The composite record of the ice shelves is chosen since these regions are influenced by low-pressure systems in the circumpolar vortex. Therefore, according to our findings in Sect. 5.2.3, in the present climate they seem to be more influenced by changes in atmospheric flow conditions than the interior plateau. On larger time scales, i.e. glacialinterglacial changes, the interior of the continent is similarly influenced by changes in general atmospheric flow patterns.

The annual SAM index shows a significant positive trend that started around 1965. Generally, both surface pressure and air temperature are supposed to be negatively correlated with the SAM index in East Antarctica since the larger pressure difference that leads to a higher SAM index is mainly caused by lower pressure around Antarctica; the consequently stronger westerlies lead to lower temperatures in East Antarctica due to the reduced meridional heat exchange (Marshall, 2013). However, whereas Neumayer air temperature only varies slightly around the long-term mean of $-16^{\circ} \mathrm{C}, \delta^{18} \mathrm{O}$ exhibits a weak, but statistically significant positive trend of $0.15 \%$ o decade ${ }^{-1}$ for the period 1950-2009. (Note that for the most recent 9 years, only cores from the Fimbul Ice Shelf contribute to the stacked record). Both features are not in line with the anticipated effect of a more positive SAM index. Surface pressure at Neumayer is statistically significantly negatively correlated with the SAM index 
$(r=-0.56)$, which would be expected; however, there is no trend towards lower pressure during the considered period. When the time series of SAM is detrended, the correlation coefficient increases to $r=-0.74$.

\section{Discussion and conclusion}

76 shallow firn cores from DML were analysed in order to assess the spatial and temporal variability of water stable isotope ratios $\left(\delta^{18} \mathrm{O}\right)$ and SMB. This was the first comprehensive study of this data set from coastal, transitional and interior DML. The large number of cores reduced depositional noise and enhanced the signal-to-noise variance ratio considerably compared to earlier investigations of subsets of the firn core data. Thus possible climatic trends could be analysed with a higher reliability than previously.

The temporal variations of $\delta^{18} \mathrm{O}$ and SMB derived from the plateau cores are distinctly different from those of the coastal cores. The SMB on the inland plateau is positively correlated to the stable isotope ratio; thus it seems to be mainly affected by temperature-dependent, thermodynamic influences, namely the saturation vapour pressure. Higher temperatures mean higher saturation vapour pressure, thus more moisture and potentially larger amounts of precipitation. On the contrary, the SMB of the coastal cores does not change in accordance with the changes in $\delta^{18} \mathrm{O}$. Precipitation and thus SMB in the coastal areas are dependent on the synoptic activity in the circumpolar trough. Usually precipitation is connected to frontal systems of cyclones moving from west to east north of the coast. Changes in the synoptic activity in and north of the circumpolar trough can have a strong impact on precipitation seasonality as well as precipitation amounts, depending on the strength and location of the trough and the type of the atmospheric circulation (zonal/meridional flow) (Schlosser et al., 2010).

Precipitation at the plateau occurs in form of diamond dust on most days of the year. It consists of very fine ice crystals that form due to radiative cooling in almost saturated air. However, it was found that also real snowfall is observed in the interior of the continent. It is connected to advection of warm air due to amplification of Rossby waves and consequent orographic lifting of the air mass. These snowfall events, even though they are rare, can bring up to $50 \%$ of the annual accumulation (Schlosser et al., 2010). Therefore the dynamic influence on stable water isotope ratios and SMB is not restricted to the coastal areas and should be discussed generally. For instance, a considerably lower ratio of winter/summer accumulation during a colder period could lead to higher annual mean $\delta^{18} \mathrm{O}$ values in the firn core because the contribution of the colder season to the annual mean would be comparatively small.
Thus a change in precipitation (and hence accumulation) seasonality could lead to a positive or negative bias in the temperatures derived from $\delta^{18} \mathrm{O}$ of an ice/firn core, depending on which seasons were preferred (Schlosser, 1999; Noone et al., 1999).

For the broad relative maximum of $\delta^{18} \mathrm{O}$ in the second half of the 19th century, the corresponding SMB is still generally lower than the average. This would mean that winter accumulation would have decreased even stronger than summer accumulation. A combination of the thermodynamic effect (generally lower SMB due to lower temperature) and dynamic effects (less precipitation events in winter due to e.g. a more zonal flow or more northern location of the sea ice edge and thus of the frontal zone) could explain the observed features. Recent data alone are not sufficient to confirm this hypothesis. More detailed investigations combined with modelling studies are necessary to shed more light on this problem.

The lack of correlation between SAM index, air temperature and $\delta^{18} \mathrm{O}$ for the ice shelf regions is highly interesting. The reasons are not yet entirely clear. Variations in SMB and its seasonality certainly play an important role here. Stronger westerlies and more intense cyclone activity do not necessarily have to lead to higher accumulation. The coastal areas are always influenced by the synoptic activity in the circumpolar trough. Higher wind speeds and faster moving cyclones alone could lead to less accumulation due to reduced duration of precipitation events. Apart from that, a more zonal flow and less meridional exchange of heat and moisture would mean that precipitation amounts for single events were smaller than in a period with negative SAM index. Thus even a higher number of precipitation events would not necessarily lead to a higher SMB. Therefore low SMB values could be due to both dynamic and thermodynamic influences.

For $\delta^{18} \mathrm{O}$, a positive SAM means a generally more local moisture source, thus less isotopic fractionation and higher $\delta^{18} \mathrm{O}$ values than in a period with negative SAM index, even though the temperature might have been relatively low.

Another important factor that influences the stable isotope ratio of Antarctic precipitation is sea ice. It determines the availability of water vapour and has a strong influence on the energy balance of the ocean, thus changing temperature and moisture amounts in the air above the water/ice surface (Noone and Simmonds, 2004). However, in the DML region sea ice does not show any systematic differences in relation to SAM (e.g. Parkinson and Cavalieri, 2012); thus the influence of sea ice on the ice core properties cannot be discussed on the given time scale for the presented data set.

Apart from all factors that affect precipitation, it should be kept in mind that also post-depositional processes alter the stable isotope ratio of the snow. Additional to the afore-mentioned redistribution of snow due to wind influence, the sublimation-deposition cycle can change the $\delta^{18} \mathrm{O}$ values. Diffusion in the pore space due to temperature gradients tends to smooth the seasonal variations (Johnsen, 1977). 
Most recent studies (Steen-Larsen et al., 2014; Hoshina et al., 2014) have shown that the interaction of the air in the pore space with the atmospheric layer just above the snow surface is more important than previously thought.
We conclude that, in the last 2 centuries, conditions in the interior DML have been fairly stable and only weakly influenced by changes in atmospheric dynamics. In the coastal areas, more complex processes are at work and the $\delta^{18} \mathrm{O}$ and SMB derived from the firn cores cannot be fully explained yet. In order to understand the temporal variability of $\delta^{18} \mathrm{O}$, a full understanding of the three-dimensional moisture transport to Antarctica is required. Additionally to firn cores and snow samples, continuous monitoring of the stable isotope ratio of water vapour combined with high-resolution atmospheric modelling would be desirable. 


\section{Appendix A}

Table A1. Location (latitude, longitude, elevation), total depth, time period and annual mean values of $\delta^{18} \mathrm{O}, \delta \mathrm{D}$ and $\mathrm{SMB}$ for all cores in western Dronning Maud Land (see Fig. 1).

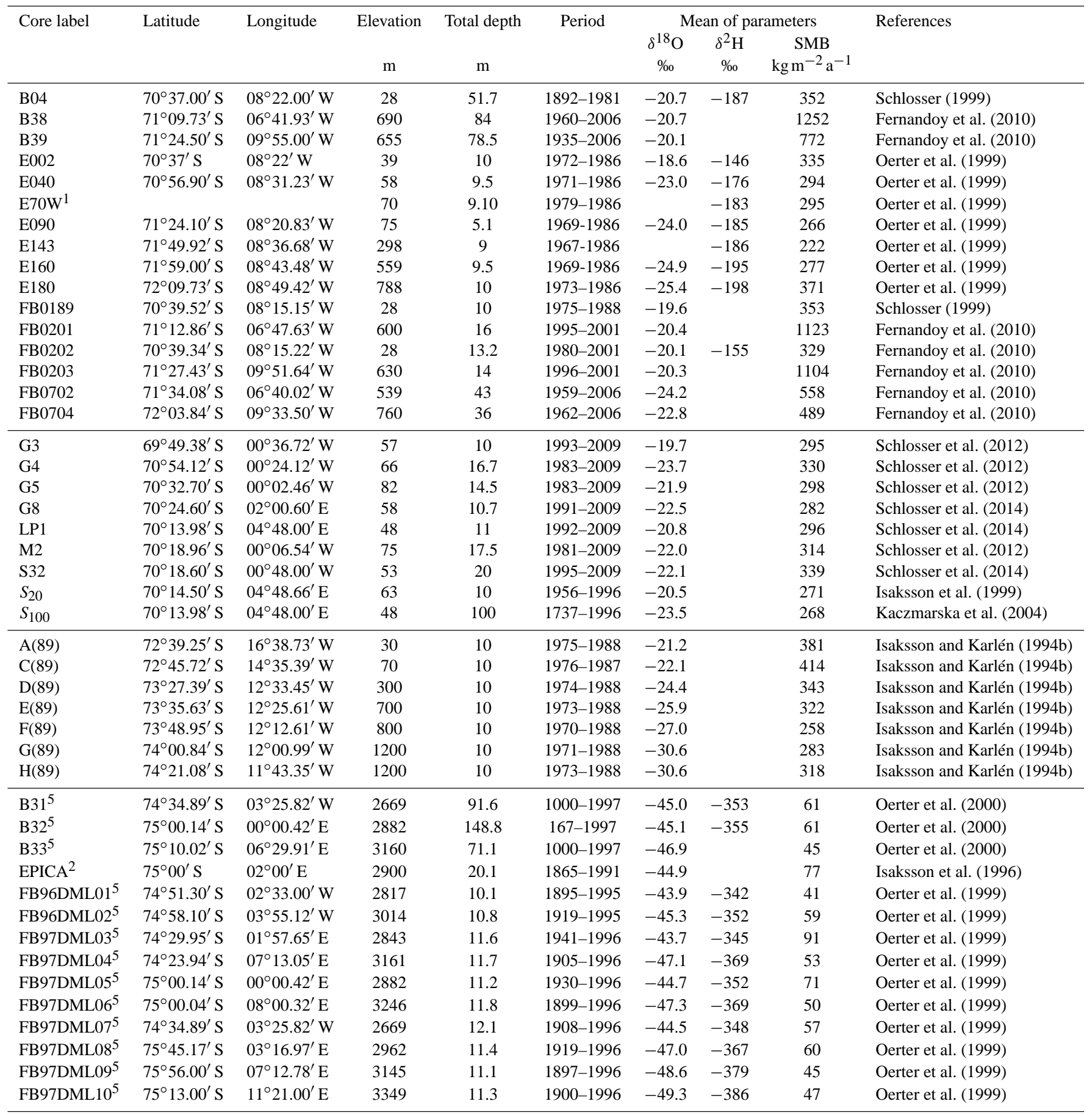


Table A1. Continued.

\begin{tabular}{|c|c|c|c|c|c|c|c|c|c|}
\hline \multirow[t]{3}{*}{ Core label } & \multirow[t]{3}{*}{ Latitude } & \multirow[t]{3}{*}{ Longitude } & \multirow{3}{*}{$\begin{array}{c}\text { Elevation } \\
\text { m }\end{array}$} & \multirow{3}{*}{$\begin{array}{l}\text { Total depth } \\
\text { m }\end{array}$} & \multirow[t]{3}{*}{ Period } & \multicolumn{3}{|c|}{ Mean of parameters } & \multirow[t]{3}{*}{ References } \\
\hline & & & & & & $\delta^{18} \mathrm{O}$ & $\delta^{2} \mathrm{H}$ & SMB & \\
\hline & & & & & & $\%$ & $\%$ & $\mathrm{~kg} \mathrm{~m}^{-2} \mathrm{a}^{-1}$ & \\
\hline FB9802 5 & $74^{\circ} 12.30^{\prime} \mathrm{S}$ & $09^{\circ} 44.50^{\prime} \mathrm{W}$ & 1439 & 26.4 & 1881-1997 & -32.5 & & 129 & Oerter et al. (2000) \\
\hline FB9803 5 & $74^{\circ} 51.10^{\prime} \mathrm{S}$ & $08^{\circ} 29.82^{\prime} \mathrm{W}$ & 2600 & 29.3 & 1921-1997 & -38.5 & -304 & 206 & Oerter et al. (2000) \\
\hline FB9804 5 & $75^{\circ} 15.02^{\prime} \mathrm{S}$ & $06^{\circ} 00.00^{\prime} \mathrm{W}$ & 2630 & 20.6 & 1801-1997 & -42.6 & & 50 & Oerter et al. (2000) \\
\hline FB9805 5 & $75^{\circ} 10.04^{\prime} \mathrm{S}$ & $00^{\circ} 59.70^{\prime} \mathrm{W}$ & 2840 & 20 & 1800-1997 & -44.6 & & 48 & Oerter et al. (2000) \\
\hline FB9807 5 & $74^{\circ} 59.82^{\prime} \mathrm{S}$ & $00^{\circ} 02.17^{\prime} \mathrm{E}$ & 2880 & 29.6 & 1758-1997 & -44.8 & & 63 & Oerter et al. (2000) \\
\hline FB9808 5 & $74^{\circ} 45.04^{\prime} \mathrm{S}$ & $00^{\circ} 59.99^{\prime} \mathrm{E}$ & 2860 & 26.8 & 1801-1997 & -43.7 & -343 & 68 & Oerter et al. (2000) \\
\hline FB9809 5 & $74^{\circ} 29.95^{\prime} \mathrm{S}$ & $01^{\circ} 57.65^{\prime} \mathrm{E}$ & 2843 & 32.9 & 1801-1997 & -44.1 & -346 & 88 & Oerter et al. (2000) \\
\hline FB9810 5 & $74^{\circ} 40.03^{\prime} \mathrm{S}$ & $04^{\circ} 00.10^{\prime} \mathrm{E}$ & 2980 & 32.2 & $1801-1997$ & -46.0 & & 86 & Oerter et al. (2000) \\
\hline FB9811 5 & $75^{\circ} 05.04^{\prime} \mathrm{S}$ & $06^{\circ} 30.00^{\prime} \mathrm{E}$ & 3160 & 23.5 & 1801-1997 & -47.9 & -375 & 58 & Oerter et al. (2000) \\
\hline FB9812 5 & $75^{\circ} 15.05^{\prime} \mathrm{S}$ & $06^{\circ} 30.10^{\prime} \mathrm{E}$ & 3160 & 16.9 & 1810-1997 & -47.1 & -369 & 40 & Oerter et al. (2000) \\
\hline FB9813 5 & $75^{\circ} 10.04^{\prime} \mathrm{S}$ & $05^{\circ} 00.02^{\prime} \mathrm{E}$ & 3100 & 21.3 & 1800-1997 & -46.1 & & 50 & Oerter et al. (2000) \\
\hline FB9814 5 & $75^{\circ} 05.02^{\prime} \mathrm{S}$ & $02^{\circ} 30.06^{\prime} \mathrm{E}$ & 2970 & 25.8 & $1801-1997$ & -45.5 & & 64 & Oerter et al. (2000) \\
\hline FB9815 & $74^{\circ} 56.95^{\prime} \mathrm{S}$ & $01^{\circ} 29.67^{\prime} \mathrm{W}$ & 2840 & 21.7 & 1801-1997 & -44.1 & & 53 & Oerter et al. (2000) \\
\hline FB9816 5 & $75^{\circ} 00.00^{\prime} \mathrm{S}$ & $04^{\circ} 29.78^{\prime} \mathrm{W}$ & 2740 & 19.7 & 1800-1997 & -43.4 & & 47 & Oerter et al. (2000) \\
\hline FB9817 5 & $75^{\circ} 00.04^{\prime} \mathrm{S}$ & $06^{\circ} 29.90^{\prime} \mathrm{W}$ & 2680 & 24.5 & 1800-1997 & -43.1 & -339 & 63 & Oerter et al. (2000) \\
\hline $\operatorname{SS} 9813^{5}$ & $74^{\circ} 58.10^{\prime} \mathrm{S}$ & $03^{\circ} 55.12^{\prime} \mathrm{W}$ & 3014 & 21 & $1801-1997$ & -46.1 & & & Oerter et al. (2000) \\
\hline$A^{3}$ & $71^{\circ} 54.00^{\prime} \mathrm{S}$ & $03^{\circ} 05.00^{\prime} \mathrm{E}$ & 1520 & 13.3 & 1971-1996 & -33.3 & & 135 & Isaksson et al. (1999) \\
\hline$B^{3}$ & $72^{\circ} 08.01^{\prime} \mathrm{S}$ & $03^{\circ} 10.51^{\prime} \mathrm{E}$ & 2044 & 12.2 & 1971-1996 & -33.4 & & 171 & Isaksson et al. (1999) \\
\hline $\mathrm{C}^{4}$ & $72^{\circ} 15.50^{\prime} \mathrm{S}$ & $02^{\circ} 53.47^{\prime} \mathrm{E}$ & 2400 & & 1965-1996 & -33.4 & & 123 & Isaksson et al. (1999) \\
\hline $\mathrm{D}^{4}$ & $72^{\circ} 30.50^{\prime} \mathrm{S}$ & $03^{\circ} 00.00^{\prime} \mathrm{E}$ & 2610 & & $1965-1996$ & -38.4 & & 116 & Isaksson et al. (1999) \\
\hline$E^{3}$ & $72^{\circ} 40.50^{\prime} \mathrm{S}$ & $03^{\circ} 39.77^{\prime} \mathrm{E}$ & 2751 & 10.1 & 1976-1996 & -40.5 & & 59 & Isaksson et al. (1999) \\
\hline $\mathrm{F}^{4}$ & $72^{\circ} 51.50^{\prime} \mathrm{S}$ & $04^{\circ} 21.08^{\prime} \mathrm{E}$ & 2840 & & $1965-1996$ & & & 24 & Isaksson et al. (1999) \\
\hline $\mathrm{G}^{4}$ & $73^{\circ} 02.50^{\prime} \mathrm{S}$ & $05^{\circ} 02.65^{\prime} \mathrm{E}$ & 2929 & & 1965-1996 & -41.2 & & 30 & Isaksson et al. (1999) \\
\hline $\mathrm{H}^{4}$ & $73^{\circ} 23.50^{\prime} \mathrm{S}$ & $06^{\circ} 27.63^{\prime} \mathrm{E}$ & 3074 & & 1965-1996 & & & 46 & Isaksson et al. (1999) \\
\hline $\mathrm{I}^{4}$ & $73^{\circ} 43.50^{\prime} \mathrm{S}$ & $07^{\circ} 56.43^{\prime} \mathrm{E}$ & 3174 & & $1965-1996$ & -44.9 & & 53 & Isaksson et al. (1999) \\
\hline $\mathrm{J}^{4}$ & $74^{\circ} 02.50^{\prime} \mathrm{S}$ & $09^{\circ} 29.50^{\prime} \mathrm{E}$ & 3268 & & 1965-1996 & & & 52 & Isaksson et al. (1999) \\
\hline $\mathrm{K}^{4}$ & $74^{\circ} 21.50^{\prime} \mathrm{S}$ & $11^{\circ} 06.22^{\prime} \mathrm{E}$ & 3341 & & 1965-1996 & -46.3 & & 44 & Isaksson et al. (1999) \\
\hline$L^{3}$ & $74^{\circ} 38.50^{\prime} \mathrm{S}$ & $12^{\circ} 47.45^{\prime} \mathrm{E}$ & 3406 & 9 & 1962-1996 & -48.0 & & 41 & Isaksson et al. (1999) \\
\hline $\mathrm{M}^{4}$ & $74^{\circ} 59.50^{\prime} \mathrm{S}$ & $15^{\circ} 00.10^{\prime} \mathrm{E}$ & 3453 & & $1965-1996$ & -49.5 & & 45 & Isaksson et al. (1999) \\
\hline$S_{15}$ & $71^{\circ} 11.50^{\prime} \mathrm{S}$ & $04^{\circ} 35.83^{\prime} \mathrm{E}$ & 800 & 15.2 & 1974-1996 & -26.7 & & 244 & Isaksson et al. (1999) \\
\hline
\end{tabular}

${ }^{1}$ Core E70W was drilled $19 \mathrm{~km}$ west of Ekström-Traverse 1987. The location is marked on page 187 in Miller and Oerter (1990).

2 The core was drilled in an area, which has been identified as a potential deep-drilling site by the EPICA research programme (Isaksson et al., 1996).

${ }^{3}$ For these cores no SMB data were available. Thus the mean values of SMB (1965-96) were adopted from Isaksson et al. (1999).

${ }^{4}$ For these cores no data were available. Thus the mean values of $\delta^{18} \mathrm{O}$ and accumulation were adopted from Isaksson et al. (1999).

5 The data of the plateau and Ekström cores are provided by Alfred-Wegener Institute (AWI) at www.pangaea.de. 
Table A2. Linear trends [\%odecade ${ }^{-1}$ ] for the stacked records of $\delta^{18} \mathrm{O}$. Significant trends according to $F$ test on the $95 \%$ (bold and underlined) and $90 \%$ confidence level (bold) are highlighted. The standard deviation of the slope is also given.

\begin{tabular}{lccccc}
\hline & $1950-2000$ & $1950-1980$ & $1960-1990$ & $1970-2000$ & $1980-2009$ \\
\hline Fimbul Ice Shelf & $\mathbf{0 . 1 8} \pm \mathbf{0 . 0 9}$ & $\underline{\mathbf{0 . 5 3} \pm \mathbf{0 . 2 2}}$ & $-0.02 \pm 0.21$ & $-0.10 \pm 0.15$ & $\mathbf{0 . 2 7} \pm \mathbf{0 . 1 6}$ \\
Ekström Ice Shelf & $\mathbf{0 . 2 7} \pm \mathbf{0 . 1 4}$ & $\underline{\mathbf{0 . 7 0} \pm \mathbf{0 . 3 0}}$ & $-0.21 \pm 0.29$ & $0.06 \pm 0.27$ & \\
Ekström Ice Shelf $(R)$ & $\mathbf{0 . 1 9} \pm \mathbf{0 . 0 8}$ & $\underline{\mathbf{0 . 6 2} \pm \mathbf{0 . 1 5}}$ & $0.20 \pm 0.18$ & $-0.07 \pm 0.18$ & $0.16 \pm 0.24^{*}$ \\
Ice shelves & $\mathbf{0 . 1 8} \pm \mathbf{0 . 0 7}$ & $\underline{\mathbf{0 . 6 7} \pm \mathbf{0 . 1 5}}$ & $-0.09 \pm 0.15$ & $-0.14 \pm 0.13$ & $\mathbf{0 . 2 8} \pm \mathbf{0 . 1 5}$ \\
Plateau & $0.08 \pm 0.06$ & $\underline{\mathbf{0 . 3 2} \pm \mathbf{0 . 0 9}}$ & $-0.07 \pm 0.10$ & $0.01 \pm 0.15$ & \\
\hline
\end{tabular}

* Trend period ends 2006

Table A3. Linear trends $\left[\mathrm{kg} \mathrm{m}^{-2} \mathrm{decade}^{-1}\right]$ for the stacked records of SMB. Significant trends according to $F$ test on the $95 \%$ (bold and underlined) and $90 \%$ confidence level (bold) are highlighted. The standard deviation of the slope is also given.

\begin{tabular}{lccccc}
\hline & $1950-2000$ & $1950-1980$ & $1960-1990$ & $1970-2000$ & $1980-2009$ \\
\hline Fimbul Ice Shelf & $-2.41 \pm 2.61$ & $-5.95 \pm 6.53$ & $5.81 \pm 5.14$ & $-2.50 \pm 4.09$ & $-6.26 \pm 4.10$ \\
Ekström Ice Shelf & $\mathbf{- 4 . 3 0} \pm \mathbf{1 . 9 4}$ & $0.78 \pm 4.04$ & $-3.81 \pm 3.66$ & $-4.95 \pm 4.46$ & \\
Ekström Ice Shelf $(R)$ & $0.39 \pm 1.42$ & $\mathbf{5 . 1 7} \pm \mathbf{2 . 7 9}$ & $\mathbf{- 4 . 4 1} \pm \mathbf{2 . 6 2}$ & $1.07 \pm 3.12$ & $-3.83 \pm 4.50^{*}$ \\
Ice shelves & $-2.17 \pm 1.77$ & $-2.89 \pm 4.28$ & $2.58 \pm 3.34$ & $-0.70 \pm 2.87$ & $\mathbf{- 7 . 2 5} \pm \mathbf{3 . 6 9}$ \\
Plateau & $1.43 \pm 0.79$ & $-0.59 \pm 1.54$ & $0.44 \pm 1.50$ & $\underline{\mathbf{5 . 2 3} \pm \mathbf{1 . 3 5}}$ & \\
\hline
\end{tabular}

* Trend period ends 2006. 
Acknowledgements. We are grateful to all members of the various expeditions, who did the field work in Antarctica and the laboratory analyses. We thank Hans Oerter for reading draft copies of this paper and providing firn and ice core data from Alfred-Wegener Institute (AWI), Helmholtz Centre for Polar and Marine Research at www.pangaea.de. Neumayer temperature data were kindly provided by Gert König-Langlo, AWI, Bremerhaven. Thanks are due to the British Antarctic Survey for the online - SAM index data. This study was funded by the Austrian Science Fund (FWF) (grants V31-N10/P-24223). This study is a contribution from Center for Ice, Climate and Ecosystems (ICE) at the Norwegian Polar Institute, Troms $\varnothing$.

Edited by: M. Schneebeli

\section{References}

Anschütz, H., Müller, K., Isaksson, E., McConnell, J. R., Fischer, H., Miller, H., Albert, M., and Winther, J.-G.: Revisiting sites of the South Pole Queen Maud Land Traverses in East Antarctica: accumulation data from shallow firn cores, J. Geophys. Res., 114, D24106, doi:10.1029/2009JD012204, 2009.

Anschütz, H., Sinisalo, A., Isaksson, E., McConnell, J. R., Hamran, S.-E., Bisiaux, M. M., Pasteris, D., Neumann, T. A., and Winther, J.-G.: Variation of accumulation rates over the last eight centuries on the East Antarctic Plateau derived from volcanic signals in ice cores, J. Geophys. Res., 116, D20103, doi:10.1029/2011JD015753, 2011.

Bromwich, D. H., Nicolas, J., Monaghan, A. J., Lazzara, M. A., Keller, L. M., Weidner, G. A., and Wilson, A. B.: Central West Antarctica among the most rapidly warming regions on Earth, Nat. Geosci., 6, 139-144, 2013.

Divine, D. V., Isaksson, E., Kaczmarska, M., Godtliebsen, F., Oerter, H., Schlosser, E., Johnson, S. J., van den Broeke, M. R., and van de Wal, R. S. W.: Tropical Pacific - high latitude south Atlantic teleconnections as seen in $\delta^{18} \mathrm{O}$ variability in Antarctic coastal ice cores, J. Geophys. Res., 114, D11112, doi:10.1029/2008JD010475, 2009.

EPICA Community Members: One-to-one coupling of glacial climate variability in Greenland and Antarctica, Nature, 444, 195198, 2006.

Fernandoy, F., Meyer, H., Oerter, H., Wilhelms, F., Graf, W., and Schwander, J.: Temporal and spatial variation of stable-isotope ratios and accumulation rates in the hinterland of Neumayer station, East Antarctica, J. Glaciol., 56, 673-687, 2010.

Fisher, D., Koerner, R. M., Paterson, W. S. B., Dansgaard, W., Gundestrup, N., and Reeh, N.: Effect of wind scouring on climatic records from ice-core oxygen-isotope profiles, Nature, 301, 205209, 1983.

Frezzotti, M., Scarchilli, C., Becagli, S., Proposito, M., and Urbini, S.: A synthesis of the Antarctic surface mass balance during the last $800 \mathrm{yr}$, The Cryosphere, 7, 303-319, doi:10.5194/tc7-303-2013, 2013.

Fujita, S., Holmlund, P., Andersson, I., Brown, I., Enomoto, H., Fujii, Y., Fujita, K., Fukui, K., Furukawa, T., Hansson, M., Hara, K., Hoshina, Y., Igarashi, M., Iizuka, Y., Imura, S., Ingvander, S., Karlin, T., Motoyama, H., Nakazawa, F., Oerter, H., Sjöberg, L. E., Sugiyama, S., Surdyk, S., Ström, J., Uemura, R., and Wilhelms, F.: Spatial and temporal variability of snow accumulation rate on the East Antarctic ice divide between Dome Fuji and EPICA DML, The Cryosphere, 5, 1057-1081, doi:10.5194/tc-5-1057-2011, 2011.

Graf, W., Oerter, H., Reinwarth, O., Stichler, W., Wilhelms, F., Miller, H., and Mulvaney, R.: Stable-isotope record from Dronning Maud Land, Antarctica, Ann. Glaciol., 35, 195-201, 2002.

Hammer, C. U., Clausen, H. B., and Dansgaard, W.: Greenland ice sheet evidence of post-glacial volcanism and its climatic impact, Nature, 288, 230-235, 1980.

Hofstede, C. M., van de Wal, R. S. W., Kaspers, K. A., van den Broeke, M. R., Karlöf, L., Winther, J.-G., Isaksson, E., Lappegard, G., Mulvaney, R., Oerter, H., and Wilhelms, F.: Firn accumulation records for the past 1000 years on the basis of dielectric profiling of six cores from Dronning Maud Land, Antarctica, J. Glaciol., 50, 279-291, 2004.

Hoshina, Y., Fujita, K., Nakazawa, F., Iizuka, Y., Miyake, T., Hirabayashi, M., Kuramoto, T., Fujita, S., and Motoyama, H.: Effect of accumulation rate on water stable isotopes of near surface snow in inland Antarctica, J. Geophys. Res., 119, 274-283, 2014.

Isaksson, E. and Karlén, W.: High resolution climatic information from short firn cores, western Dronning Maud Land, Antarctica, Clim. Change, 26, 421-434, 1994a.

Isaksson, E. and Karlén, W.: Spatial and temporal patterns in snow accumulation, western Dronning Maud Land, Antarctica, J. Glaciol., 40, 399-409, 1994b.

Isaksson, E. and Melvold, K.: Trends and patterns in the recent accumulation and oxygen isotope in coastal Dronning Maud Land, Antarctica: interpretations from shallow ice cores, Ann. Glaciol., 35, 175-180, 2002.

Isaksson, E., Karlén, W., Gundestrup, N., Mayewski, P., Whitlow, S., and Twickler, M.: A century of accumulation and temperature changes in Dronning Maud Land, Antarctica, J. Geophys. Res., 101, 7085-7094, 1996.

Isaksson, E., van den Broeke, M. R., Winther, J.-G., Karlöf, L., Pinglot, J. F., and Gundestrup, N.: Accumulation and proxytemperature variability in Dronning Maud Land, Antarctica, determined from shallow firn cores, Ann. Glaciol., 29, 17-22, 1999.

Johnsen, S. J.: Stable isotope homogenization of polar firn and ice, Symposium on Isotopes and Impurities in Snow and Ice (Proceedings of the Grenoble Symposium, 1975), IAHS-AISH Publication No. 118, 210-219, 1977.

Johnsen, J. S., Clausen, H. B., Dansgaard, W., Gundestrup, N., Hammer, C. U., Andersen, U., Andersen, K. K., Hvidberg, C. S., Dahl-Jensen, D., Steffensen, J. P., Shoji, H., Sveinbjörnsdóttir, A. E., Withe, J., Jouzel, J., and Fisher, D.: The $\delta^{18} \mathrm{O}$ record along the Greenland Ice Core Project deep ice core and the problem of the possible Eemian climatic instability, J. Geophys. Res., 102, 26397-26410, 1997.

Kaczmarska, M., Isaksson, E., Karlöf, L., Winther, J.-G., Kohler, J., Godtliebsen, F., Ringstad Olsen, L., Hofstede, C. M., van den Broeke, M. R., van de Wal, R. S. W., and Gundestrup, N.: Accumulation variability derived from an ice core from coastal Dronning Maud Land, Antarctica, Ann. Glaciol., 39, 339-345, 2004.

Karlöf, L., Winther, J.-G., Isaksson, E., Kohler, J., Pinglot, J. F., Wilhelms, F., Hansson, M., Holmlund, P., Nyman, M., Pettersson, R., Stenberg, M., Thomassen, M. P. A., van der Veen, C., and van de Wal, R. S. W.: A 1500 year record of accumulation 
at Amundsenisen western Dronning Maud Land, Antarctica, derived from electrical and radioactiv measurements on a $120 \mathrm{~m}$ ice core, J. Geophys. Res., 105, 12471-12483, 2000.

Karlöf, L., Isaksson, E., Winther, J.-G., Gundestrup, N., Meijer, H. A. J., Mulvaney, R., Pourchet, M., Hofstede, C. M., Lappegard, G., Pettersson, R., van den Broeke, M. R., and van de Wal, R. S. W.: Accumulation variability over a small area in east Dronning Maud Land, Antarctica, as determined from shallow firn cores and snow pits: some implications for ice-core records, J. Glaciol., 51, 343-352, 2005.

King, J. C. and Turner, J.: Antarctic Meteorology and Climatology, Cambridge University Press, Cambridge, 409 pp., doi:10.1017/CBO9780511524967, 1997.

König-Langlo, G., King, J. C., and Pettré, P.: Climatology of the three coastal Antarctic stations Dumont D'Urville, Neumayer, and Halley, J. Geophys. Res., 103, 10935-10946, 1998.

Marshall, G. J.: Trends in the southern annular mode from observations and reanalyses, J. Climate, 16, 4134-4143, 2003.

Marshall, G. J.: Half-century seasonal relationship between the Southern Annular Mode and Antarctic temperatures, Int. J. Climatol., 27, 373-383, 2007.

Marshall, G. J., Orr, A., and Turner, J.: A Predominant Reversal in the Relationship between the SAM and East Antarctic Temperatures during the Twenty-First Century, J. Climate, 26, 51965204, 2013.

Masson-Delmotte, V., Hou, S., Ekaykin, A., Jouzel, J., Aristarain, A., Bernardo, R. T., Bromwich, D., Cattani, O., Delmotte, M., Falourd, S., Frezzotti, M., Galée, H., Genoni, L., Isaksson, E., Landais, A., Helsen, M. M., Hoffmann, G., Lopez, J., Morgan, V., Motoyama, H., Noone, D., Oerter, H., Petit, J., Royer, A., Uemera, R., Schmidt, G. A., Schlosser, E., Simões, Steig, E. J., Stenni, B., Stievenard, M., van den Broeke, M. R., van de Wal, R. S. W., van de Berg, W. J., Vimeux, F., and White, J. W. C.: A review of Antarctic surface snow isotopic composition: observations, atmospheric circulation, and isotopic modeling, J. Climate, 21, 3359-3387, 2008.

Melvold, K., Hagen, J. O., Pinglot, J. F., and Gundestrup, N.: Large spatial variation in accumulation rate in Jutulstraumen ice stream, Dronning Maud Land, Ann. Glaciol., 27, 231-238, 1998.

Miller, H. and Oerter, H.: Die Expedition ANTARKTIS-V mit FS Polarstern 1986/87: Bericht zu den Fahrtabschnitten ANT-V/45, Ber. Polarforsch., 57, 207 pp., doi:10013/epic.10057, 1990.

Monaghan, A. J., Bromwich, D., and Wang, S.: Recent trends in Antarctic snow accumulation from Polar MM5 simulations, Philos. T. R. Soc. A, 364, 1683-1708, 2006.

Monaghan, A. J., Bromwich, D. H., Chapman, W., and Comiso, J. C.: Recent variability and trends of Antarctic near-surface temperature, J. Geophys. Res., 113, D04105, doi:10.1029/2007JD009094, 2008.

Noone, D. and Simmonds, I.: Sea ice control of water isotope transport to Antarctica and implications for ice core interpretation, J. Geophys. Res., 109, D07105, doi:10.1029/2003JD004228, 2004.

Noone, D., Turner, J., and Mulvaney, R.: Atmospheric signal and characteristics of accumulation in Dronning Maud Land, Antarctica, J. Geophys. Res., 104, 19191-19211, 1999.

Oerter, H., Graf, W., Wilhelms, F., Minikin, A., and Miller, H.: Accumulation studies on Amundsenisen, Dronning Maud Land, Antarctica, by means of tritium, dielectric profiling and stable- isotope measurements: first results from the 1995-1996 and 1996-1997 field seasons, Ann. Glaciol., 29, 1-9, 1999.

Oerter, H., Wilhelms, F., Jung-Rothenhäusler, F., Göktas, Miller, H., Graf, W., and Sommer, S.: Accumulation rates in Dronning Maud Land, Antarctica, as revealed by dielectric-profiling measurements of shallow firn cores, Ann. Glaciol., 30, 27-34, 2000.

Oerter, H., Graf, W., Meyer, H., and Wilhelms, F.: The EPICA ice core from Dronning Maud Land: first results from stable-isotope measurements, Ann. Glaciol., 39, 307-312, 2004.

Parkinson, C. L. and Cavalieri, D. J.: Antarctic sea ice variability and trends, 1979-2010, The Cryosphere, 6, 871-880, doi:10.5194/tc-6-871-2012, 2012.

Rignot, E., Jacobs, S., Mouginot, J., and Scheuchl, B.: Ice-shelf melting around Antarctica, Science, 341, 266-270, 2013.

Röthlisberger, R., Bigler, M., Sommer, S., Stauffer, B., Junghans, H. G., and Wagenbach, D.: Technique for continuous highresolution analysis of trace substances in firn and ice-cores, Environ. Sci. Technol., 34, 338-342, 2000.

Rotschky, G., Holmlund, P., Isaksson, E., Mulvaney, R., Oerter, H., van den Broeke, M. R., and Winther, J.-G.: A new surface accumulation map for western Dronning Maud Land, Antarctica, from interpolation of point measurements, J. Glaciol., 53, 385398, 2007.

Rott, H., Rack, W., Skvarca, P., and De Angelis, H.: Northern Larsen Ice Shelf, Antarctica: further retreat after collapse, Ann. Glaciol., 34, 277-282, 2002.

Schlosser, E.: Effects of seasonal variability of accumulation on yearly mean $\delta^{18} \mathrm{O}$ values in Antarctic snow, J. Glaciol., 45, 463468, 1999.

Schlosser, E. and Oerter, H.: Seasonal variations of accumulation and the isotope record in ice cores: a study with surface snow samples and firn cores from Neumayer station, Antarctica, Ann. Glaciol., 35, 97-101, 2002a.

Schlosser, E. and Oerter, H.: Shallow firn cores from Neumayer, Ekströmisen, Antarctica: a comparison of accumulation rates and stable-isotope ratios, Ann. Glaciol., 35, 91-96, 2002 b.

Schlosser, E., Duda, M. G., Powers, J. G., and Manning, K. W.: Precipitation regime of Dronning Maud Land, Antarctica, derived from Antarctic Mesoscale Prediction System (AMPS) archive data, J. Geophys. Res., 113, D24108, doi:10.1029/2008JD009968, 2008.

Schlosser, E., Manning, K. W., Powers, J. G., Duda, M. G., Birnbaum, G., and Fujita, K.: Characteristics of high-precipitation events in Dronning Maud Land, Antarctica, J. Geophys. Res., 115, D14107, doi:10.1029/2009JD013410, 2010.

Schlosser, E., Anschütz, H., Isaksson, E., Martma, T., Divine, D., and Nøst, O.-A.: Surface mass balance and stable oxygen isotope ratios from shallow firn cores on Fimbulisen, East Antarctica, Ann. Glaciol., 53, 70-78, 2012.

Schlosser, E., Anschütz, H., Divine, D., Martma, T., Sinisalo, A., Altnau, S., and Isaksson, E.: Recent climate tendencies on an East Antarctic ice shelf inferred from a shallow firn core network, J. Geophys. Res., 119, 6549-6562, 2014.

Sinisalo, A., Anschütz, H., Aasen, A. T., Langley, K., von Deschwanden, A., Kohler, J., Matsuoka, K., Hamran, S.-E., Øyan, M.-J., Schlosser, E., Hagen, J. O., Nøst, O. A., and Isaksson, E.: Surface mass balance on Fimbul ice shelf, East Antarctica: comparison of field measurements and large-scale studies, J. Geophys. Res., 118, 11625-11635, 2013. 
Sommer, S., Appenzeller, C., Röthlisberger, R., Hutterli, M. A., Stauffer, B., Wagenbach, D., Oerter, H., Wilhelms, F., Miller, H., and Mulvaney, R.: Glacio-chemical study spanning the past $2 \mathrm{kyr}$ on three ice cores from Dronning Maud Land, Antarctica, 1. Annually resolved accumulation rates, J. Geophys. Res., 105, 29411-29421, 2000a.

Sommer, S., Wagenbach, D., Mulvaney, R., and Fischer, H.: Glaciochemical study spanning the past $2 \mathrm{kyr}$ on the three ice cores from Dronning Maud Land, Antarctica, 2. Seasonally resolved chemical records, J. Geophys. Res., 105, 29423-29433, 2000 b.

Steen-Larsen, H. C., Masson-Delmotte, V., Hirabayashi, M., Winkler, R., Satow, K., Prie, F., Bayou, N., Cuffey, K. M., DahlJensen, D., Dumont, M., Guillevic, M., Kipfstuhl, S., Landais, S., Popp, A., Risi, T., Steffen, K., Stenni, B., and Sveinbjornsdottir, A. E.: What controls the isotopic composition of greenland surface snow?, Clim. Past., 10, 377-392, doi:10.5194/cp-10-3772014, 2014.
Stocker, T. F., Qin, D., Plattner, G.-K., Tignor, M., Allen, S. K., Boschung, J., Nauels, A., Xia, Y., and Midgley, P. M. (Eds.): IPCC, 2013:The Physical Science Basis. Contribution of Working Group I to the Fifth Assessment Report of the Intergovernmental Panel on Climate Change, Cambridge University Press, Cambridge, UK, New York, NY, USA, 1535 pp., 2013.

Swithinbank, C.: The regime of the ice shelf at Maudheim as shown by stake measurements. Norwegian-British-Swedish Antarctic Expedition, 1949-1954, Scientific Results. Glaciology I. Norsk Polarinstitutt, 41-57, 1957.

Turner, J., Colwell, S. R., Marshall, G. J., Lachlan-Cope, T. A., Carleton, A. M., Jones, P. D., Lagun, V., Reid, P. A., and Iagovkina, S.: Antarctic climate changes during the last 50 years, Int. J. Climatol., 25, 279-294, 2005.

Wilhelms, F., Kipfstuhl, J., Miller, H., Heinloth, K., and Firestone, J.: Precise dielectric profiling of ice cores: a new device with improved guarding and its theory, J. Glaciol., 44, 171-174, 1998. 